\title{
A múlt értékei, a jelen kutatásai, a jövendő céljai az Erdélyi Múzeum-Egyesületben
}

BITAY ENIKŐ

„Az erdélyi magyar tudományos törekvések kérdésével csak az foglalkozzék, akiben van szeretetig menó objektivitás és objektivitásig menő szeretet, aki tehát bele képes helyezkedni azokba a csaknem sorstragédiáknak nevezhetó személyes életküzdelmekbe, amelyeket az erdélyi tudósok minden időben az ellenséges körülményekkel, a fagyasztó közönnyel, a lenézéssel, a kicsinyességgel és testvérharcokkal folytattak."

\section{Bevezeto}

- Erdélyi Múzeum-Egyesület (EME) arra törekedett és törekszik, A hogy múködésével hidat verjen a múlt értékei, a jelen kutatásai, a jövendő eredményei közé, s mindezzel a magyar tudományt, az erdélyi magyar közösséget szolgálja. A múlthoz való ragaszkodás nem csupán az elődeink munkássága előtti tisztelgést jelenti, hanem mindazt a tudományos törekvést és értékrendet, amely az erdélyi tudományosság megmaradásához, fenntartásához szükséges. A neves erdélyi filozófus, Tavaszy Sándor a tudományosság lényegét nemzetünk számára I930-ban így határozta meg: „A nemzeti élet szerkezetében a tudományosság az az intellektuális gerinc, amelytól függ a nemzeti szellemi élet fennmaradása". ${ }^{2}$ Ugyancsak ő állapította meg a magyar tudományosság múltjáról, hogy „... nemcsak kapcsoló pontokat

1 Tavaszy Sándor: Magyar tudományos törekvések Erdélyben. EM XXXV(I930). 217.

2 Uo. 215. 
nyújt a biztos és határozott irányú tudományos fejlödés számára, hanem nagy erkölcsi erőforrás is, amely tudományos existenciánk fenntartását táplálja”. ${ }^{3}$

Az Erdélyi Múzeum-Egyesület a Romániában élő magyarság tudományos és múvelődési életének civil szervezete, amely gr. Mikó Imre kezdeményezésére alakult meg az I859. november 23-26. között Kolozsvárott megtartott közgyúlésen (akkor Erdélyi Múzeum-Egylet néven). Megalakulása óta a történelmi viszontagságok, a kisebbségi lét nehézségei ellenére hú maradt felvállalt céljaihoz, s intézményes kerete mindvégig az erdélyi tudományos élet jelentős meghatározója volt. Noha létrejötte és múködésének fenntartása komoly erőfeszítéseket követelt, mindig voltak erre hivatott elkötelezett tagok, vezetők, támogatók, akik az EME-eszmét szívügyüikként kezelték, s megtartották/múködtették az EME intézményes keretét az erdélyi tudományos élet fenntartásához.

\section{Előzmények és megvalósulás}

Erdélyben, a „kisebbik magyar hazában” a I8. század közepén jelentkezett először az akadémiai gondolat, a magyar tudományos élet megszervezésének szándéka. A „tudomány- és múzeumszervező gondolat első erdélyi harcosai”-nak sorát, ahogyan Szabó T. Attila nevezte őket, ${ }^{4}$ Bod Péter egyháztörténész nyitotta meg, aki i760-ban vetette fel egy tudós társaság létrehozásának szükségességét, majd a könyvtáralapító Batthyány Ignác püspök szándékozott történetkutató intézetet létrehozni, sajnos sikertelenül. Aranka György az I79I. évi országgyúlésen létrehozta az Erdélyi Magyar Nyelvmíveló Társaságot, majd I792-ben megszervezte a Régi Kézirások Társaságát, a régi erdélyi történeti és emlékiratok, kéziratban heverő írások kiadása végett. Döbrentei Gábor I8I4-ben indította el az első erdélyi tudományos folyóiratot, az Erdélyi Muzéumot, s egy akadémiai jellegú társaság tervét dolgozta ki a Magyar Tudós Társaság mintájára. ${ }^{5}$ Bölöni Farkas Sándor I829-ben az erdélyi múzeum felállításának gondolatát veti fel, sajnos közöny fogadja tervét.

$\mathrm{Az}$ EME létrejöttének első lépése az a jelentős adományfelajánlás, melyet írásban az I842-es országgyúlésen terjesztett elő gr. Kemény József és gr. Kemény Sámuel egy Nemzeti Múzeum felállításának céljából. Kemény

3 Uo.

4 Szabó T. Attila: Az Erdélyi Múzeum-Egyesület története és feladatai. EME, Kolozsvár, 1942. 6.

5 Kelemen Lajos: Az Erdélyi Múzeum-Egyesület múltja és jelene. EME, Kolozsvár, 1909. I-3. 
József mintegy I5 ooo kötet könyvet, több ezer kéziratból, illetve oklevélből álló gyújteményt, Kemény Sámuel pedig jelentős ásványgyújteményét kívánta átadni a nemes célra. Az országgyúlés örömmel fogadta a felajánlást, a megvalósulás azonban sokáig húzódott. A múzeumfenntartó egyesület megalapítását a szabadságharc leverése után, az abszolutizmus kedvezőtlen körülményei között gr. Mikó Imre vette kézbe, megmozgatva a teljes erdélyi társadalmat s megszerezve a kormányzati jóváhagyást is. Valóságos nemzeti ünnep volt az I859. november 23-26. között tartott kolozsvári közgyúlés, amely az egyesület hármas célját ekképpen határozta meg: múzeum felállítása s fenntartása, a múzeumi gyújtemények tudományos feldolgozása, illetve a tudomány és múvelődés magyar nyelven való terjesztése.

Az EME megalakulását követően mindig voltak fordulópontok, amikor tevékenységét, múködését az éppen kialakult politikai, társadalmi helyzet, avagy szükségletek határozták meg. Első évtizedét a gyújtemények nagyarányú fejlesztése határozta meg a legkülönbözőbb társadalmi rétegek adományai révén, elhelyezésük is megoldódott a gr. Mikó Imre adományozta nyári villában. I867-től kezdve kivette részét a korszerúsödés útjára lépett Magyarország tudományos életének fejlődésében.

Amikor az ország második egyetemének megalapítása került napirendre I872-ben, Kolozsvár azzal nyerte meg a versenyt, hogy gyúijteményeinek használatát évi bér fejében átengedte a létesítendő új felsőoktatási intézménynek. A Mikó-villa tizenkét hold kiterjedésú kertjét szintén felajánlotta a tervezett egyetemi építkezések céljára, itt épültek fel később a klinikák

Az EME és az egyetemet fenntartó állam között létrejött szerződés értelmében a különféle gyújiteményeket (könyvtár, kézirattár, később levéltár, természettudományos gyújtemények, érem- és régiségtár stb.) közösen megállapított terv szerint fejlesztették, az egyesület pedig tudományos folyóiratokat adott ki (Erdélyi Múzeum, Orvostudományi Értesítő), amelyek az egyetem szakemberei számára is megjelenési lehetőséget biztosítottak.

$\mathrm{Az}$ I9I9-es impériumváltást követően az EME nemzeti tudományos jelentősége még inkább felértékelődött, múködésének folyamatos fenntartása ezért volt fontos a kisebbségben éló magyar tudós társadalomnak, ennek jegyében múk ködik ma is. A két világháború közötti időszak erdélyi magyar tudományos törekvéseit Jancsó Elemér három korszakra bontja a Magyar tudományos élet Erdélyben I9I8-tól napjainkig címú tanulmányában: a „próbálkozások kora” (I918-1926 között), majd a „csendes erőgyújtés" (I926-I930), s végül a "fellendülés" (I930-I937). Véleménye szerint ez utóbbi korszak eredményei kiemelkedőek, „ekkor erósödik meg az EME és lép ismét az aktív munkálkodó útjára”. 193I-tôl újraindult az Erdélyi Múzeum 


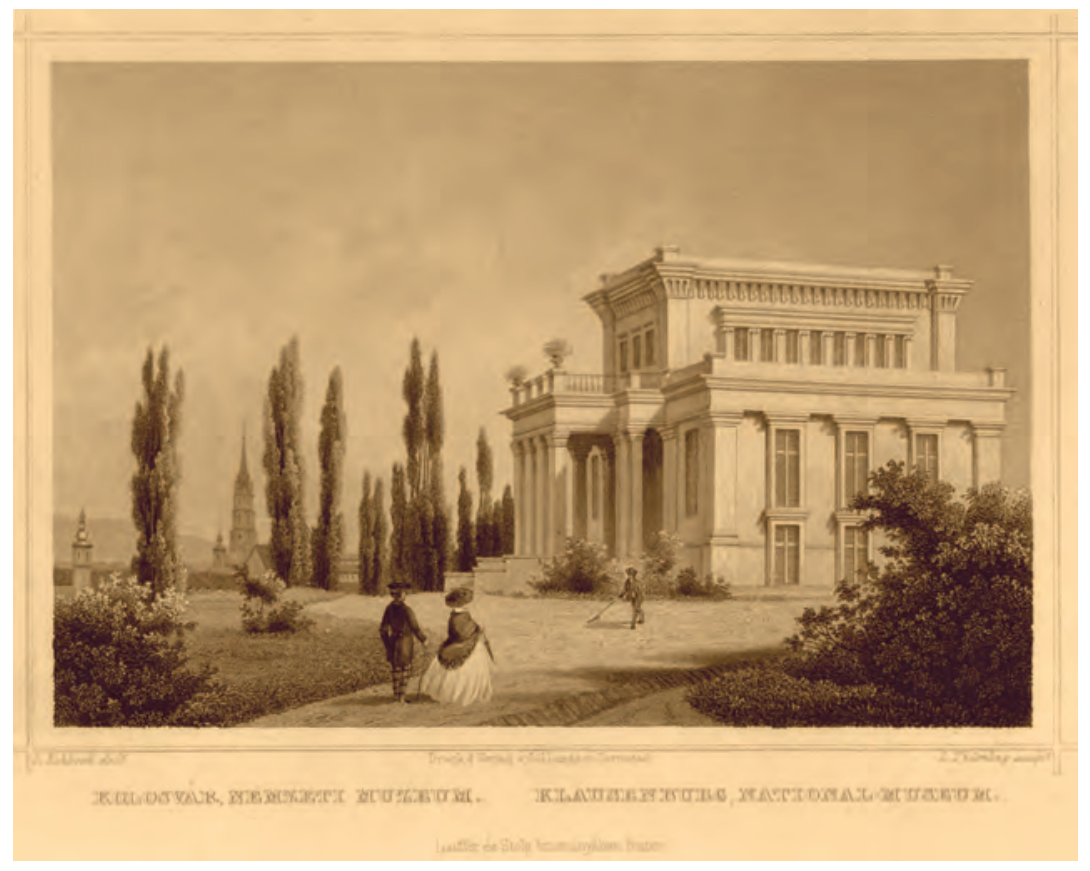

Gr. Mikó Imre nyári villája, melyet az EME-nek adományozott

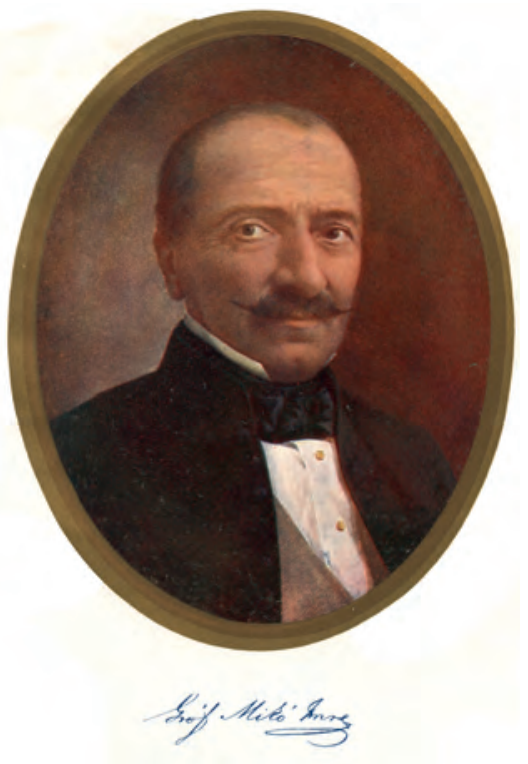

Gr. Mikó Imre portréja

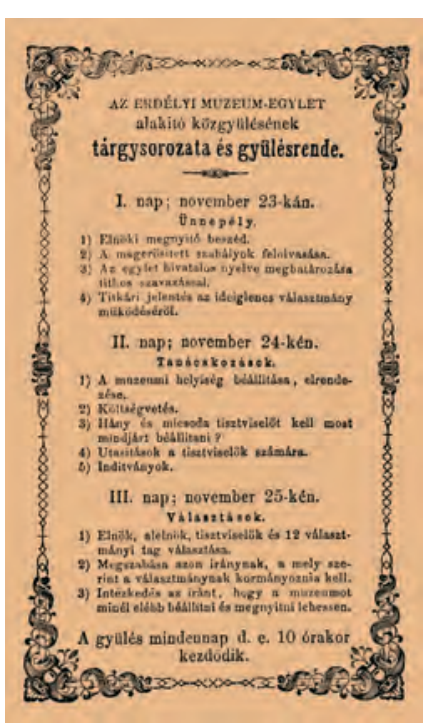

Az EME alakitó közgyúlésének tárgysorozata és gyúlésrendje 
folyóirat évi négy számmal, a rendszeres tudományos előadások pedig nagyszámú közönséget vonzottak. ${ }^{6}$

Fontos megemlíteni, hogy az EME sajátos arculatú, többrétegú, több pillérre támaszkodó, de nem kizáró jellegú tudományos intézmény volt; mellette számos új intézmény, rövidebb-hosszabb ideig múködő tudományos múhely jött létre. 1940 őszén az Erdélyi (Magyar) Tudományos Intézetet azzal a céllal alapították Kolozsváron, hogy a humán tudományok, elsősorban a történelem és népélet tanulmányozásának szentelje tudományos erőit. Az államilag fizetett, ún. intézeti tanárok mellett az egyetemről meghívott külső tanárok kapcsolódtak be az itt folyó tudományos munkába. A későbbiekben néhány egyetemi oktató a politikai viszonyok kedvezőtlen változása miatt az EME-ben mintegy „menedékre lelt”. Az egykori munkatársak között ott találjuk Szabó T. Attilát, aki 1936-tól levéltári munkatársként tevékenykedett, s aki 1940-47 között mindvégig szívügyének tekintette és fontosnak tartotta az Egyesületben vállalt tudományos missziójának (pl. az Erdélyi Múzeum és a Tudományos Füzetek szerkesztési munkálatainak) továbbvitelét. Venczel József szociológus az egyetemről való erőszakos eltávolítása után (1947) az EME főlevéltárosaként tudományos kutatómunkát végezhet.

$\mathrm{Az}$ EME, mint intézményes keret, mindig a gerincét képezte az erdélyi magyar tudományos életnek, s igyekezett az időközben kialakult társintézményekkel jó összhangban, eredményesen múködni.

I950-ben azonban a kommunista diktatúra betiltotta az EME múködését, s újraindítására csak az I989-es változások után kerülhetett sor. Ez év decemberében néhány kolozsvári értelmiségi kifejezte kívánalmát a Bolyai Egyetem és az EME mihamarabbi visszaállítását illetően, s a következő év januárjában néhányan (Jakó Zsigmond, Kiss András, Kántor Lajos, Csetri Elek, Benkő Samu, Jenei Dezső, Nagy Jenő, Sipos Gábor stb.) össze is gyúltek annak érdekében, hogy megvitassák az intézmény újraindításával kapcsolatos teendőket.

A mintegy ötvenéves kényszerszünet nem szorította vissza az EME tagságának tudományos törekvéseit, csendben, de eredményesen folytatták munkájukat, ki-ki egyszemélyes otthoni múhelyében, s a szakmai megbeszélésekhez is találtak alkalmat. Például a tudósok számára a vasárnapi bükki séták kínáltak lehetőséget a beszélgetésre Jakó Zsigmond, Szabó T. Attila, Kiss András, Benkő Samu és mások részvételével.

6 Jancsó Elemér: Magyar tudományos élet Erdélyben 1918-tól napjainkig. Bp. 1937. Láthatár, I. sz. I4-20, 2. sz. 74-80. http://ispmn.gov.ro/uploads/oo6Jancso_Magyar\%2otudomanyos\%2oelet.pdf 
Az 1990 márciusában újraalakult EME igyekezett tehát folytatni azt a küldetést és társadalmi szerepet, amelyet alapítói megálmodtak, és intézményi rendszerét az új körülményekhez képest kívánta kiépíteni.

\section{Az EME küldetése, célja}

Az Erdélyi Múzeum-Egyesület küldetése az anyanyelvứ tudománymúvelés, a gyújteményeibe tartozó kulturális örökség megóvása és tudományos feldolgozása, továbbá a tudományos ismeretek terjesztése a romániai magyarság körében. Az EME feladatának tekinti, hogy az erdélyi magyar hagyományokat ápolja, az egyetemes magyar tudományosságot szolgálja, és az európai kultúra és tudomány értékeit gyarapítsa. Rendezvényei keretében ismerteti a nemzetközi és a helyi tudományos eredményeket, és ezáltal teljesíti a romániai magyarság múvelődése, szellemi gazdagodása érdekében vállalt feladatát.

Mint említettük, az EME több pilléren álló intézmény, mely hét szakosztályt, hat fiókegyesületet, ifjúsági szakcsoportokat, kutatóintézetet, könyvtárat, digitális adattárat és kiadót múlködtet stratégiai céljai megvalósítása érdekében.

\section{Az EME tízéves múltja (2005-20I5), tudományos törekvéseinek mérföldkövei}

Jelen írás röviden áttekinti az EME elmúlt tízéves tudományos tevékenységét, fontosabb mérföldköveit, törekvéseit és eredményeit. Ez a periódus egybeesik azzal az időszakkal, melyben az EME kialakította és megszilárdította az itt folyó tudományos kutatás intézményes kereteit, korszerúsítette és szakosztályokkal bővitette tudományterületi tevékenységét, illetve a tudomány terjesztésében, népszerúsítésében vállalt szerepet. E tevékenység fontosabb állomásai:

- 2005-2006-ban akkreditáltattuk az EME kiadóját, valamint két folyóiratát: az Erdélyi Múzeumot és az Orvostudományi Értesítőt.

- 2005-2006-ban létrehoztuk az EME Kutatóintézetét. ${ }^{7}$

- 2007 januárjában az Információs és dokumentációs központot avattuk a központi könyvtárunkban, melynek keretében az Elektronikus infor-

7 A 2006. március II-én tartott közgyúlés fogadta el az EME Kutatóintézetének szervezeti és múködési szabályzatát. 
mációs szolgáltatás (EISZ), illetve a könyvállományunk elektronikus katalogizálása is beindult.

- 2007-ben akkreditáltattuk, pontosabban minósittettük a kutatóintézetet, ezáltal romániai állami (Országos Felsőoktatási Kutatási Tanács) kutatási forrásokat sikerült pályáznunk, s meg is nyernünk.

- 2008-tól kezdve meghatározott idejú kutatási programokat indítottunk külsó munkatársak számára, kezdetben az intézmény által megszabott témákban, majd fokozatosan teret biztosítottunk a különböző szakterületeken való kibontakozásra, a szakosztályok által javasolt és igényelt témákban is. A felvállalt programokba a fiatal kutatók bevonása volt a cél, ugyanakkor ezzel a szakosztályokat is erősíteni kívántuk a kutatás-népszerúsítési és a kiadványokban vállalt szerepük mellett.

- 20Io-ben avattuk az intézményi repozitóriumot, az Erdélyi digitális adattárat, mely a tudományos kutatáshoz szükséges adatok tárolására, szolgáltatására s az eredmények megjelentetésére, terjesztésére egyaránt lehetőséget nyújt.

- 20II-től az EME múködését programokban határoztuk meg, s pályáztattuk a megvalósítani kívánt projekteket. ĺgy a tervezés, múködtetés és megvalósítás követése tervszerú volt, illetve adott periódusra voltak kalkulálva, logikai rendszerben múködtetve.

- A 20II-től indult Kolozsvári Magyar Napok augusztusi forgatagába aktívan kapcsolódtunk be rendezvényeinkkel a szakosztályok révén, ezzel is erősítve s népszerúsítve tudományos tevékenységüket, s tettük széles körben ismertté eredményeinket.

- 20I2-ben avattuk a Periodikák az Erdélyi digitális adattárban (PEDA) modult. A program célja: a ritkaságszámba menő, Erdélyben megjelent, sokak által ma is használt szakmai folyóiratok digitalizálása; ekkor került sor a 150 éves Keresztény Magvető digitalizált változatának ünnepélyes bemutatójára, melynek teljes digitalizált anyaga felkerült az EDA-ba, s ma is folyamatosan bővül új számaival.

- 20I2-ben a román akkreditációs intézet újra változtatott a kiadók besorolási követelményein. Az EME kiadója megtartotta korábbi B kategóriás minősítését a történelem és a kultúratudományok kategóriában, majd megszerezte a $\mathrm{B}$ kategóriát a filológia tárgykörére, valamint a $\mathrm{C}$ kategóriát az előadó-múvészetek témakörben is. Az Erdélyi Múzeum folyóirat is megőrizte a $\mathrm{B}$ minősítést, csupán a kategóriák változtak a bizottság döntése alapján: történelem és kultúratudományok, filozófia és filológia. Ezenkívül az Erdélyi Tudományos Füzetek sorozatot is elismertettük. 
- 20I3. december 7-én újraalakult a csíkszeredai fiókegyesület (Balázs Lajos tagtársunk kezdeményezésére).

- 2013-tól üzemel könyvtárunk új katalógusa, amely a Hun-Téka rendszerben múködik. Az indítófelület elérhetósége: http://portal.eme.ro.

- 20I4-ben két kiállitással is igyekeztünk gyújteményeinket láthatóvá tenni (Kolozsvár ipartörténete és az első világháború centenáriumához kapcsolódó témákban).

- 20I4. július 29-én intézményünk és a Lucian Blaga Központi Egyetemi Könyvtár együttmúködési megállapodást kötött, ennek révén több közös digitalizálási programot is megvalósíthattunk.

- 20I4-ben megalakult az EME sepsiszentgyörgyi fiókegyesülete (Bíró Boróka Júlia tagtársunk kezdeményezésére).

- 2015. május 4-én a Magyar Tudományos Akadémiával kötött megújitott együttmúködési megállapodás ünnepélyes aláírására került sor Budapesten az MTA évi rendes közgyúlésén.

- 2015-ben a Magyar Tudomány Napja Erdélyben (MTNE) rendezvényünk plenáris ülésére Lovász László matematikus akadémikust, az MTA elnökét hívtuk meg elóadás tartására, illetve a romániai magyar tudósokat foglalkoztató intézményeknek adtunk teret saját intézményük kutatási tevékenységeinek bemutatására.

Mindezek után tekintsük át az EME szerkezetét, s ismerjük meg felvállalt programjait, különös tekintettel az elmúlt Io év munkásságára.

\section{Az EME mint integrált tudományos keretintézmény szerkezete, struktúrája}

Az EME szerkezetét áttekintve láthatjuk, hogy intézményünk az egyes tudományágak múvelőit és a tudománypártoló érdeklődőket - mintegy 2680 tagot $^{8}$ - egyaránt összefogja. Ez a sajátossága egyben előnye is a több pilléren múködő intézménynek. Saját kutatóintézettel, szolgáltató jellegú tudományos könyvtárral rendelkezik; digitális adattárat, tudományos szakosztályokat, ifúsági szakcsoportokat, kutatómúhelyeket, fiókegyesületeket, illetve könyvkiadót múködtet.

82015 év elején. 


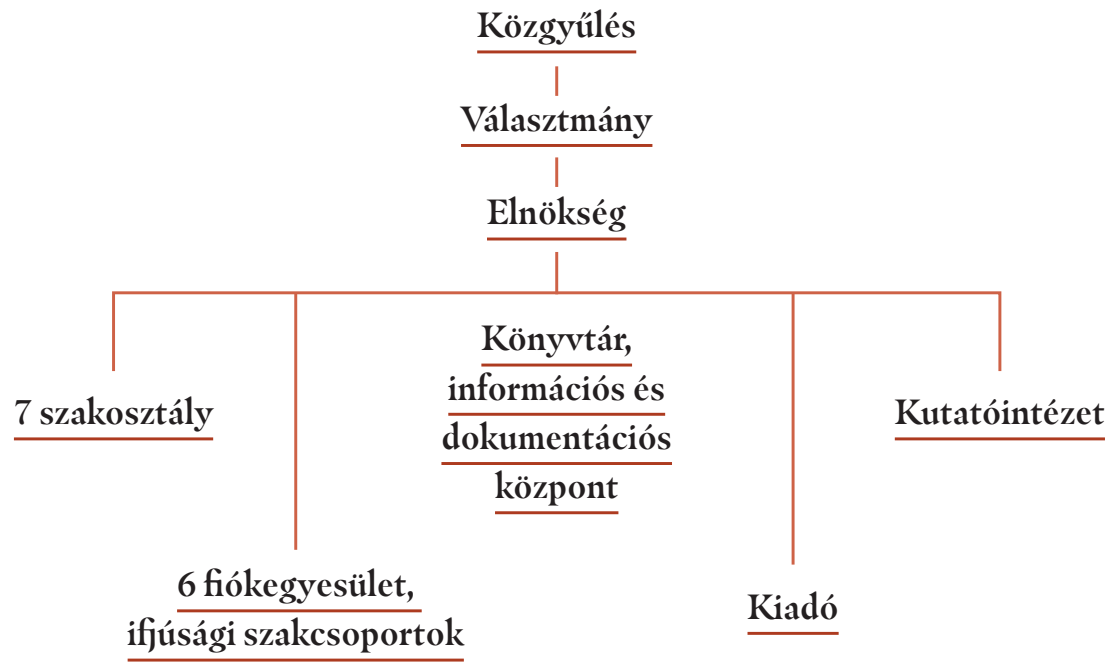

Az EME szervezetifelépitése

Az EME sajátos struktúrája révén a kutatás iránt érdeklődők között megtalálni mind a tapasztalt, nyugalmazott egyetemi oktatót, mind az aktív oktatót, kutatót, aki által a fiatal nemzedék (kutató, egyetemi hallgató, doktorandusz) is bevonható a tudományos élet vérkeringésébe.

Röviden áttekintjük az EME szerkezeti egységeit, melyek a tudományos élet és a kutatások elősegítésére hivatottak.

SZAKOSZTÁLYOK, IFJÚSÁGI SZAKCSOPORTOK, KUTATÓMÚHELYEK, FIÓKEGYESÜLETEK

A szakosztályok tevékenysége sokrétú és szerteágazó, legfóképpen ismeretterjesztő, tudomány-népszerúsítő rendezvényeket tartanak. Az egyes szakterületeken a tudományos közösséget erősítik, s kutatási tevékenységeket is felvállalnak. Aktívan ápolják az intézményközi kapcsolatokat, és folyamatosan erósítik az egyetemeken folyó oktatói, kutatói tevékenységeket. Ugyanakkor tevékenységükkel hozzájárulnak az EME kutatási, könyvkiadási programjaihoz. Az EME-nek jelenleg hét szakosztálya fogja át a különböző szakterületek érdeklődőit és tudománymúvelőit: I. Bölcsészet-, Nyelv- és Történettudományi Szakosztály, II. Természettudományi Szakosztály, III. Orvos- és Gyógyszerésztudományi Szakosztály, IV. Jog-, Közgazdaság- és Társadalomtudományi Szakosztály, V. Múszaki Tudományok Szakosztály, VI. Matematikai és Informatikai Szakosztály, VII. Agrártudományi Szakosztály. 
Az EME felkarolja, támogatja az utánpótlást biztosító, a kutatási munkára ösztönző iffúsági szakcsoportok tevékenységét, mint például a GEKKO (Geológus Egyetemisták Kolozsvári Kutató Osztálya), KOMATE (Kolozsvári Magyar Történészhallgatók Egyesülete).

Az EME-nek jelenleg 6 múködő fiókegyesülete van: Csíkszereda, Gyergyószentmiklós, Marosvásárhely, Sepsiszentoyörgy, Szilágysomlyó, Zilah és vidéke. A fiókegyesületek létrejötte és múködése a helyi tagtársak igényeinek megfelelően alakul. A fiókegyesületek révén az EME által felvállalt tudományos tevékenységek kiterjednek olyan vidékekre is, ahol nagy szükség van a tudományos élet fellendítésére.

Egyesületünk tudományos tevékenységet folytató múhelyeket, szakcsoportokat is támogat. Így például a Pósta Béla Egyesületet, mely a romániai magyar régészek reprezentatív szervezete. Tevékenységük szorosan összhangban van az EME kutatási törekvéseivel, s a közös kutatási programokban is részt vállalnak, akárcsak az EME által kiadott Dolgozatok az Erdélyi Múzeum Érem- és Régiségtárából címúi időszakos kiadvány szerkesztésében. 20I5-ben fiatal építómérnökök által alapított szervezet, a Meeting - Erdélyi Magyar Épitőmérnök Társaság partnerként csatlakozott intézményünkhöz, kiemelten tudomány-népszerúsíto, múszaki szakmai fejlesztő és közösségépítő tevékenységük az EME Múszaki Tudományok Szakosztályának céljaival összhangban van, s ezt jól kiegészítik a specifikus szakma révén is.

\section{AZ EME KÖNYVTÁRA, AZ INFORMÁCIÓS \\ ÉS DOKUMENTÁCIÓS KÖZPONTJA}

Az Erdélyi Múzeum-Egyesületben folyó kutató és tudomány-népszerüsító munka már a kezdetektől a könyvtárra alapozódott. A könyvállomány folyamatosan bővül részint adományok, részint vásárlás és csereprogramok útján. A központi épület mellett a Jordáky-ház és a Lőrinczi-ház is várja olvasóit, ahol az érdeklődők egyaránt tanulmányozhatnak szépirodalmi és tudományos jellegú kiadványokat, ugyanakkor a Lơrinczi-ház lehetővé teszi személyi hagyatékok, kéziratok tanulmányozását is. Az EME Információs és Dokumentációs Központja biztosítja a digitális dokumentumokhoz való hozzáférést is. Beszélhetünk itt az EISZ, az ADT adatbázisokról, illetve az EME saját repozitóriumáról, az Erdélyi digitális adattárról.

\section{AZ EME KIADÓJA}

Az Erdélyi Múzeum-Egyesület kiadója a rendszeresen megjelentetett szakfolyóiratok mellett évente több tudományos kötetet ad ki önállóan vagy más kiadókkal közösen. Az EME kiadója odafigyel arra is, hogy a hagyo- 
mányos könyvterjesztési stratégiák mellett (könyvterjesztői hálózat, online bolt, könyvtári cserepéldányok) jelen legyen a különböző könyves eseményeken. Egyrészt minden friss kiadványunkat bemutatjuk az EME székházában, felkért szakértők közremúködésével, másrészt részt veszünk a hazai és magyarországi fesztiválokon is.

\section{AZ EME KUTATÓINTÉZETE}

A Kutatóintézet ma I3 belső munkatársat foglalkoztat, akik a történelem, irodalomtudomány, nyelvészet és filozófia területén végzik kutatásaikat. Munkájuk eredményességét forráskiadványaik, monográfiáik, tanulmányaik bizonyítják. Ugyanakkor a kutatóintézet három osztályában az EME külső kutatók munkáját is felvállalja. A többnyire egyetemi hallgatókból álló munkacsoportok tanárok irányítása alatt végzik kutatásaikat, eredményeiket konferenciákon, illetve az EME kiadványaiban (tanulmánykötetekben, folyóiratokban) mutatják be.

\section{Az EME programjai}

Az EME programjai által egyszerre folytat kutatást, nevelói, oktatói szerepet is ellát, ugyanakkor közzéteszi és terjeszti a kutatási eredményeket, mindeközben tudományos közösséget épít a különböző szakterületeken.

Miért a programok? Az EME tudományos tevékenysége sokrétú: megtalálni a fiatal pályakezdőt, az aktív oktatót, a tapasztalt szaktekintélyt; szerkezeti egységben összehangoltan csakis úgy múk ködhet mindez, ha pontosan körülírt programokban határozzuk meg a résztevékenységeket. Ez a pályáztatás szempontjából is előnyös, hiszen a kialakított programok konkrét pályázatokba ültethetők, s ekként az eredmények láthatóvá tétele is egyszerúbb, folyamatossága biztosított. A programok követik a struktúrát, a tudományos életben szerepet vállalók személyi összetételét s mindazon célokat, melyeket az EME mint intézmény felvállalt.

Az EME programjai:

- I. az Információs és dokumentációs központ (könyvtár és adattár) múködtetése, fejlesztése;

- II. kutatóintézetünk, kutatási programjaink;

- III. szakmai képzések;

- IV. az Erdélyi digitális adattár múködtetése és fejlesztése;

- V.tudományos könyv- és folyóiratkiadás.

A következőkben ezeket a programokat mutatjuk be röviden. 


\section{INFORMÁCIÓS ÉS DOKUMENTÁCIÓS KÖZPONT, KÖNYVTÁRAK}

Az EME három múködő könyvtári részleget tart fenn közel 70 ooo kötettel, melyeket az egyesület tagjai, a kolozsvári magyar egyetemisták, valamint az intézmény és kiadványai iránt érdeklődők vesznek igénybe.

Az elmúlt Io év során közel I3 ezer könyvvel és folyóirattal bővült könyvtárunk, melyek online katalógus által is kereshetők (http:/portal. eme.ro). Könyvtáraink és kézirattárunk állománya folyamatosan gyarapodik, cserekapcsolatok és felajánlott hagyatékok által. Kézirattárunk gyújteményének lajstroma online elérhető, illetve kutatható a helyszínen.

\section{AZ EME KUTATÓINTÉZETÉNEK TEVÉKENYSÉGE A Kutatóintézet rövid bemutatása}

Az EME Kutatóintézete elsósorban az ún. honismereti tudományok múvelésére jött létre, létrehozása néhai Jakó Zsigmond nevéhez fúződik, az ő szellemét követik a kutatóintézet munkatársai is. A kutatási programok célja az erdélyi magyarság történetéhez és kultúrájához szorosan kapcsolódó történeti és nyelvészeti források feltárása.

A Kutatóintézetnek három osztálya összefogja a humán és társadalomtudományi, a múszaki és természettudományi, valamint az orvostudományi és gyógyszerészeti kutatási projekteket.

Jelenleg az intézet igazgatója Kovács András múvészettörténész, az MTA külső tagja, az EME alelnöke.

Mielőtt rátérnénk kutatási projektjeink és eredményeink konkrét bemutatására, szóljunk röviden az EME kutatóintézete megalakulásának körülményeiről, főbb feladatköreiről is.

Tevékenységének újrakezdése óta a hagyományos munkaterületek felvállalása mellett törekedett az EME az új kihívásoknak is eleget tenni. Ezért I995-ben fóállású tudományos munkatársat alkalmazott a nyelvész Tamásné Szabó Csilla személyében, feladatául pedig Szabó T. Attila hatalmas nyelvtörténeti szótárának a befejezését túzte ki. Így alakult ki a jövendő kutatóintézet magja, a nyelvész kollégához Tonk Sándor történész tanítványai csatlakoztak, akik a kora újkori erdélyi történelmi források kiadására vállalkoztak. Mellettük dolgozott egy fiatal medievista, aki Jakó Zsigmond középkori oklevéltárának sajtó alá rendezésében segédkezett.

2002-ben tehát, amikor Jakó Zsigmond a Magyar Tudomány Napja alkalmából szervezett első erdélyi fórumon áttekintette az EME kutatóintézetének feladatait, egy már valójában jól múködő kutatócsoportot vizsgált, amelynek azonban akkor még hiányzott a hivatalos intézményi kerete. 
Jakó Zsigmond (1916-2008) akadémikus a hazai és magyarországi medievisztika kiemelkedő képviselöje, az Erdélyi MúzeumEgyesület egykori elnöke, a kutatóintézet alapítója
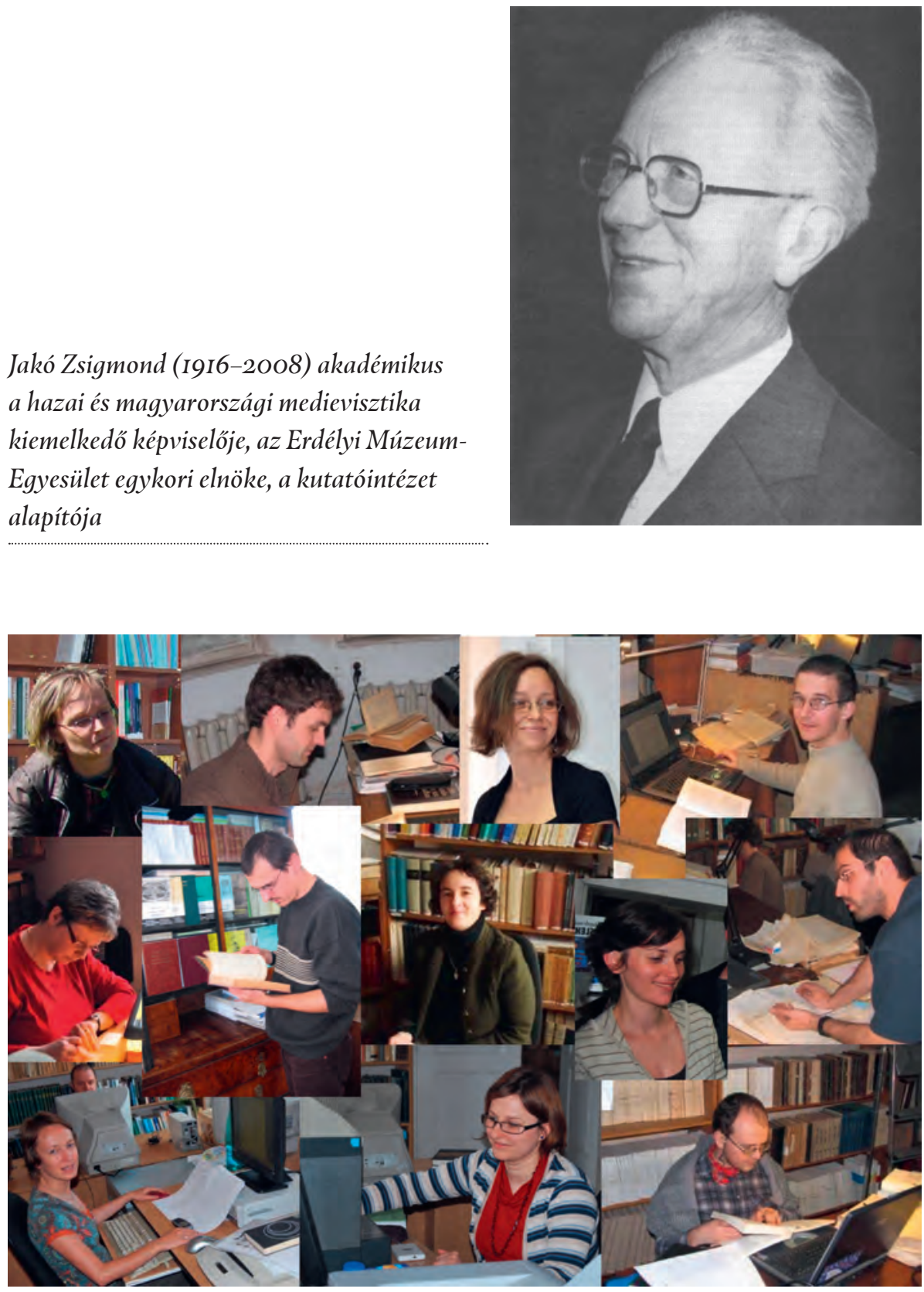

Az EME Kutatóintézetének fóállású munkatársai 
„Ami pedig egy korszerú erdélyi kutatóintézet kifejlesztését illeti, véleményem szerint abból a tényból kellene kiindulni, hogy a magyar múvelódési örökség nagyobbik és régebbi része nem a mai Magyarországon, hanem a Felvidéken és Erdélyben található. Ennek kapcsán a magyar müvelódésért felelös tényezőknek rövidesen, de legkésőbb a két szomszéd állam EU-tagságát követően szembe kell nézniük egy-egy széles spektrumú kutatóintézet felállitásának szükségével a magyar tudományos érdekek biztositására. Ilyen intézet létesitésének leggazdaságosabb megoldásául az kínálkozna, hogy az erdélyi, illetve felvidéki tudományosság igényeit kielégitó kutatóintézet lássa el ezt a szolgálatot is az egész magyar tudományosság számára. Ez lehetne az erdélyi/felvidéki tudományosság sajátos fó feladata, funkciója az újra egyesült magyar tudományosságban. Tehát a helyi, erdélyi/felvidéki kutatáson és a magyarországi kutatási igényeken kivül a külföldi magyar intézetekéhez hasonló feladatokat is egyetlen intézet láthatná el. Ebben a formában egy ilyen intézet talán könnyebben elfogadható lenne a barátságtalan többségi társadalmak számára is." ${ }^{9}$ Mivel egy ilyen széles spektrumú intézmény nem jött létre, az EME kutatóintézete, többnyire pályázatokból befolyó támogatások révén, a nemzeti tudományok múvelését és megismertetését túzte ki elsőrendú céljául. Mintegy tízévi vajúdás után, Jakó Zsigmond professzor kitartó törekvéseinek, az EME vezetőségének és a magyar állam támogatásának köszönhetően, a román állam érdektelensége ellenére 2006-ban hivatalosan is létrejött az EME kutatóintézete.

A I3 fóállású kutató tevékenysége négy szakterületet ölel fel: történelem, nyelvészet irodalomtörténet és filozófia. Tudományáganként a következő jelentősebb kutatásokat és eredményeket mutatjuk be.

\section{A Kutatóintézet foállású munkatársainak tevékenysége}

A történészek forráskutatásai ${ }^{10}$

A kutatóintézet ma 8 történészt foglalkoztat, akik szoros együttmúködésben állnak az MTA Történettudományi Intézetével. Itt kell megjegyeznünk, hogy munkatársaink közül többen is Bolyai-ösztöndíjat nyertek (Bogdándi Zsolt, Fejér Tamás, Gálfi Emőke és Szász Anikó), kutatóink befogadó intézménye is az MTA Történettudományi Intézete volt. A két intézet együttmúködési megállapodásának értelmében összehangolja a kutatásokat, közös konferenciákat és könyvbemutatókat szervez.

9 Jakó Zsigmond: Az erdélyi magyar tudományosság fordulóponton. Erdélyi Múzeum 65 (2003).

3-4. sz. IO4.

$10 \mathrm{Az}$ adatok összegzésében Bogdándi Zsolt kutató volt segítségemre. 
A Kutatóintézet keretében folyó, alapkutatásnak minősülő, forrásfeltáró programokat az alábbiakban időrend szerint, röviden tekintjük át. ${ }^{11}$

Az ERdÉlyi oKMÁNYTÁr KIADÁSA. A Kutatóintézet középkorász munkatársai folytatják a Jakó Zsigmond által elindított Erdélyi okmánytár szerkesztését, ezáltal pedig az erdélyi medievisztika legfontosabb feltáró vállalkozását végzik. A forráskiadványból eddig mintegy 4000 kivonatot tartalmazó négy kötet jelent meg, jelenleg az ötödik kötet szerkesztése folyik. Külön érdeme a kiadvány eddigi köteteinek, hogy önálló forráskritikai alapokra helyezkedik, az egyes darabokat - a korábbi közlésektől eltérően - lényegre szorítkozó, világos kritikai megjegyzésekkel látja el. A sorozat tehát a kritika rostáján megtisztított forrásanyaghoz juttatja a történetkutatást. A köteteket esetenként térképmellékletek egészítik ki, amelyek a korabeli Erdély településtörténeti, egyházigazgatási vagy más jellegú viszonyairól tájékoztatnak.

A GYULAFEHÉRVÁRI ÉS KOLOZSMONOSTORI HITELESHELYEK SZEKULARIZÁCIÓ (I556) UTÁNI JEGYZŐKÖNYVEINEK KÖZREADÁSA. A szerkesZtők célja a hiteleshelyek I575. évi újjászervezésétől fogva a I7. század végéig fennmaradt jegyzőkönyveinek közzététele. Eddig a gyulafehérvári hiteleshely jegyzőkönyveinek az I577-I6I3 közötti bejegyzéseiből készült I4IO regeszta jelent meg nyomtatásban a sorozat első két köteteként. Apafi Mihály fejedelem uralkodása végéig (I690) terjedő, tehát a fejedelemségkori gyulafehérvári káptalani protocollumok teljes anyagából mintegy 7-80oo kivonat elkészítése várható. A tervek szerint a kolozsmonostori konvent jegyzőkönyveinek az I575. évi újjászervezés és az I590. esztendő közötti bejegyzéseit öleli majd fel az első regesztakötet, melynek megjelenése 2015 végére várható.

Az erdélyi fejedelmek Liber Regiusainak köZreadása. A szerkesztők mindegyik fejedelem reánk maradt összes Királyi könyvét, tekintet nélkül a kötetek számára, egyetlen, külön egységnek tekintve dolgozzák fel regesztákban. A kiadvány minden egyes uralkodó teljes anyagát, szigorú időrendbe sorolva, egyetlen számsorral fúzi egységbe, mely minden fejedelem esetében újrakezdődik. Minthogy a feldolgozás nem kézirati kötetenként, hanem uralkodónkénti időrendben történik, a regesztasorok élére mindegyik fejedelem esetében az átírt vagy csak említett, esetleg századokkal korábbi oklevelek kerülhetnek. Mindegyik regesztakötet tartalmazza a

11 A kutatási programokat Fejér Tamás angol nyelven megjelent tanulmánya alapján mutatjuk be, lásd Tamás Fejér: Editing and Publishing Historical Sources in the Research Institute of the Transylvanian Museum Society. Transylvanian Review Vol. XXI, Supplement no. 2. 20I2. 9-30. 

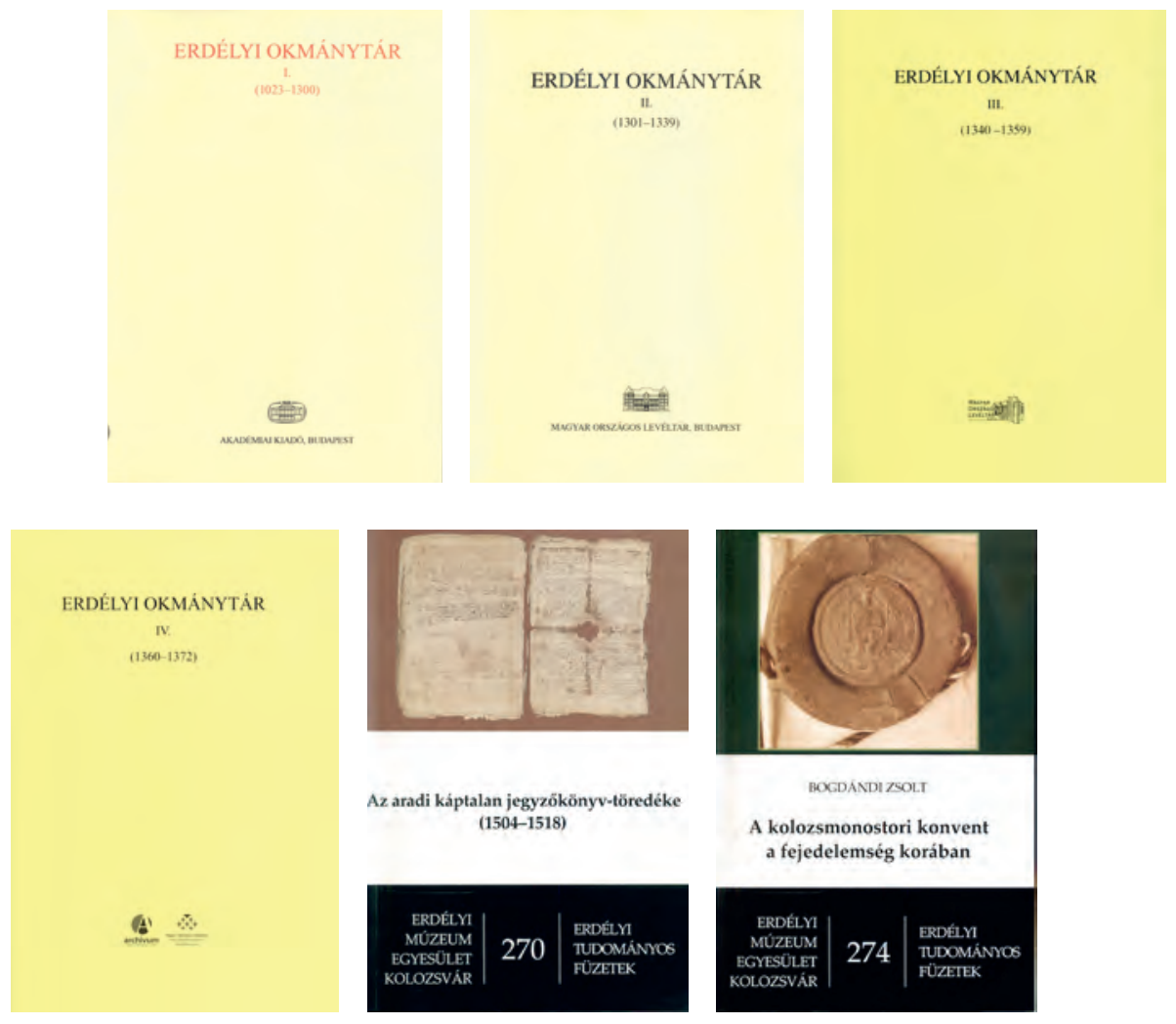

Az aradi káptalan jegyzókōnyv-töredéke (1504-1518)
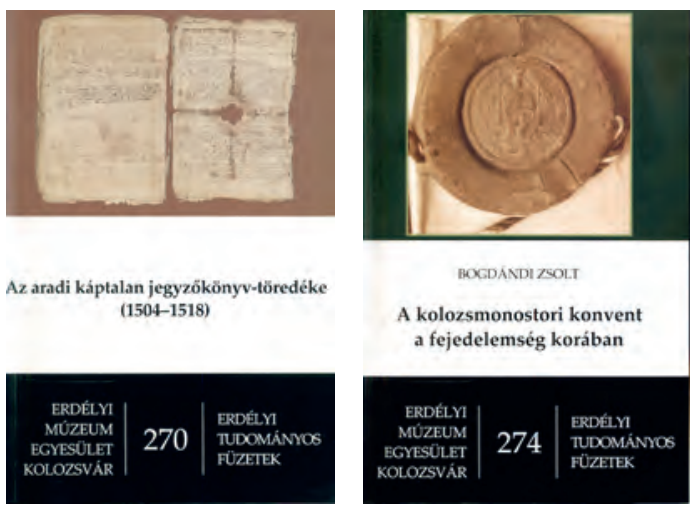

ROCDDANDIZSOLT

A kolozsmonostori konvent a fejedelemség korában
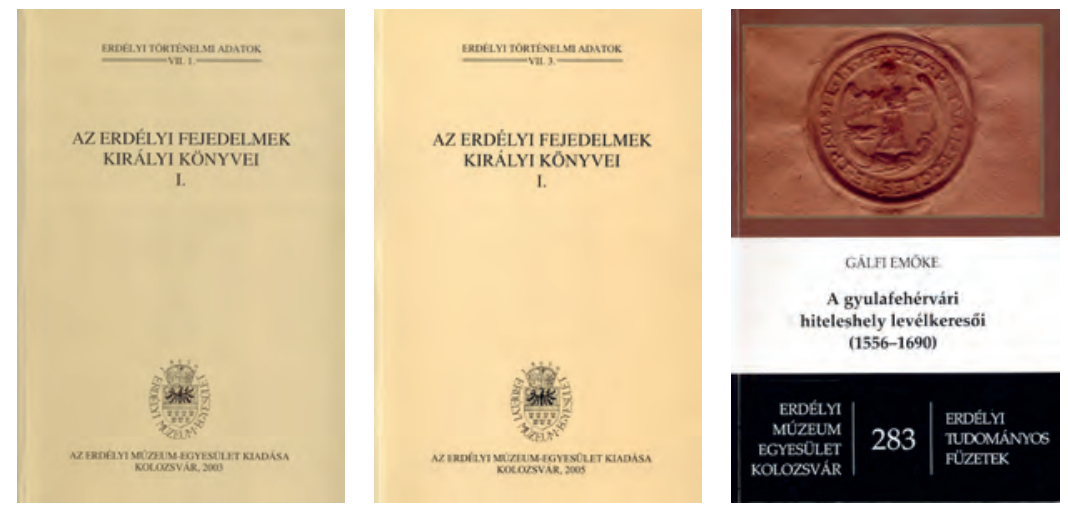

GÄLFIEMÓKE

A gyulafehérvári hiteleshely levélkeresối (1556-1690)

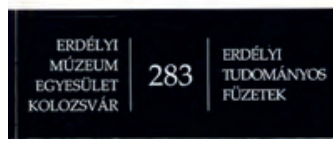

feldolgozott Liber regiusok rövid kodikológiai leírását. Eddig János Zsigmond, Báthory Kristóf és Báthory Zsigmond fejedelmeknek az I569-I602 közötti évekből fennmaradt, hat kötet Királyi könyvének 2540 regesztája jelent meg nyomtatásban a sorozat első két köteteként.

SzÉKElY LÁSZló önÉletírÁSÁNAK PUBlikáláSA. Az I972-ben Budapestre, az Országos Széchényi Könyvtár Kézirattárába került Székely-féle önéletírás még a nyolcvanas években felkeltette az erdélyi történészek 
figyelmét. Jakó Zsigmond szorgalmazására került a kézirat fényképmásolata Erdélybe, s kezdődött volna el ennek kiadásra való előkészítése, mely vélhetően a Kriterion Könyvkiadó igen nagy népszerüségnek örvendő ún. fehér sorozata részeként látott volna nyomdafestéket. Azonban a rendszerváltást követően az erdélyi történész társadalom lehetőségei megváltoztak, az elbeszélő források kiadása pedig teljesen háttérbe szorult. Intézetünk újkorral foglalkozó munkatársa, Fehér Andrea 20Io-tól foglalkozik a kézirattal, az önéletíró személyével, s ennek a többévi kutatómunkának eredménye a jövő év során megjelenő kötet. Székely László önéletírása az MTA BTK Történettudományi Intézet (Budapest) és az Erdélyi Múzeum-Egyesület (Kolozsvár) közös kiadásában jelenik meg.

Jelentőségüket tekintve az említett forrásközlések az Intézet keretében tevékenykedő történészek eddigi munkásságának a gerincét alkotják. Ezek mellett természetesen számos regesztakiadvány, monográfia és tanulmány jelent meg az Intézet felállítása óta.

Hegyi Géza kutatásai kiterjednek Erdély település- és politikatörténetére, birtok- és igazgatástörténetre, valamint az erdélyi egyház középkori történetére. Ugyancsak ő készíti Erdély egyházi archontológiáját, amely a tartomány középkori egyháztörténetének alapvetését jelenti. W. Kovács András - a cegei Wass család levéltára 1542 előtti regesztáinak sajtó alá rendezése mellett - kutatásai a vajdai tisztség fejlődéséhez és az erdélyi megyék középkori múk ödéséhez kapcsolódnak. Elkészítette az erdélyi vármegyék középkori archontológiáját és a magyar vonatkozású romániai oklevélközlések bibliográfiáját. Gálfi Emőke közölte az aradi káptalan késő középkori jegyzőkönyvtöredékét, amely ennek a hiteleshelyi intézménynek az egyetlen ilyen jellegú fennmaradt forrása, és monográfiát írt a gyulafehérvári káptalan fejedelemségkori személyzetéről. Bogdándi Zsolt a másik erdélyi hiteleshely, a kolozsmonostori konvent történetét dolgozta fel, és több tanulmányt jelentetett meg a fejedelemségkori központi bíráskodással és bírói személyzettel kapcsolatosan. Fejér Tamás a Báthory-korszak fejedelmi kancelláriájának múködéséről és személyzetéről közölt alapvető jelentőségú tanulmányokat. Mindezek a közlemények egy készülő fejedelemségkori archontológia előmunkálatai. Az erdélyi Királyi könyvek kiadásán dolgozó munkacsoport tagjaként Pakó László Kolozsvár fejedelemségkori történetéhez köthetó tanulmányokat jelentetett meg, egyebek mellett a városi jogügyigazgatói intézmény múlködésével kapcsolatosan.

Ha számszerúsíteni kívánjuk az eredményeket, azt mondhatjuk, hogy a forráskiadási programok keretében eddig kb. 7700 oklevél magyar nyelvú kivonatának közreadására került sor, s további ıooo kiadása várat még 
magára. Ezek egy része ismeretlen volt a szakközönség előtt, éppen ezért kiadványaink nagy népszerúségnek örvendenek, hiszen a hivatkozások száma (az eddig megjelentek a Magyar Tudományos Múvek Tára szerint, az Erdélyi okmánytár köteteit leszámítva közel ıooo független hivatkozást gyújtöttek össze) is ezt bizonyítja. Az intézet említett munkacsoportjai által múvelt feltárás nélkül az erdélyi, de az egyetemes magyar történetkutatás területén sem lehetséges előrelépés a történettudomány számára.

A fentebb bemutatott programok azért is fontosak, mert a történettudomány múvelését állami finanszírozással végző Román Akadémia projektjei elsősorban az erdélyi történelem román vonatkozásai iránt érdeklődnek, így a kutatóintézet munkatársaira olyan feladat hárul, amely révén lehetövé válik a korabeli Erdély történetének több szempontú s magyar vonatkozású megismerése is.

\section{A nyelvészek kutatásai}

2005-2015 között az EME kutatói, Tamásné Szabó Csilla és András Zselyke a leggazdagabban adatolt magyar nyelvtörténeti szótár, az Erdélyi magyar szótörténeti tár szerkesztésén és kiadásán dolgoztak. Munkájuknak köszönhetően 3 kötetet sikerült megjelentetni. ${ }^{12}$

Amellett, hogy munkatársaink a Szótörténeti tár nyomtatott megjelentetésén dolgoztak, 2009-től kezdődően célul túzték ki a teljes sorozat digitalizálását is, amely a korrektúrázás és aktualizálás után felkerült az EME repozitóriumába, az EDA-ba. Az EME céljai között szerepel egy olyan adatbázis létrehozása, amely újabb nyelvészeti kutatások elindítójaként szolgálhat az ott tárolt anyagnak köszönhetően. Öt kötetet mára már sikerült is felvinni az online felületre.

Kutatóink a Debreceni Egyetem Onomasztikai Kutatócsoportjával közremúködésben elkezdték az erdélyi magyar helynévkincs elektronikus feldolgozását, valamint a felmerülő hiányok pótlását. A Magyar nemzeti helynévtár elnevezésú adatbázis létrehozása rendkívül jelentős feladat, azt is mondhatnánk, hogy nemzeti érdek, amelynek megvalósulását a Magyar Nyelvstratégiai Intézet is támogatja. Ezzel párhuzamosan, a digitális változat kiegészítéseképpen, külön kötet megjelentetését is tervezzük. A digitális feldolgozáshoz képest a kötet új szempontokkal is bóvülni fog, hiszen az ELTE kutatócsoportjával és a debreceni intézet munkatársaival való egyeztetésnek megfelelően feldolgozásra kerülnek Szabó T. Attila történeti helynévgyújtésének eredményei is.

12 A XII. kötet 2005-ben, a XIII. 2009-ben és a XIV. kötet 20I4-ben jelent meg. 


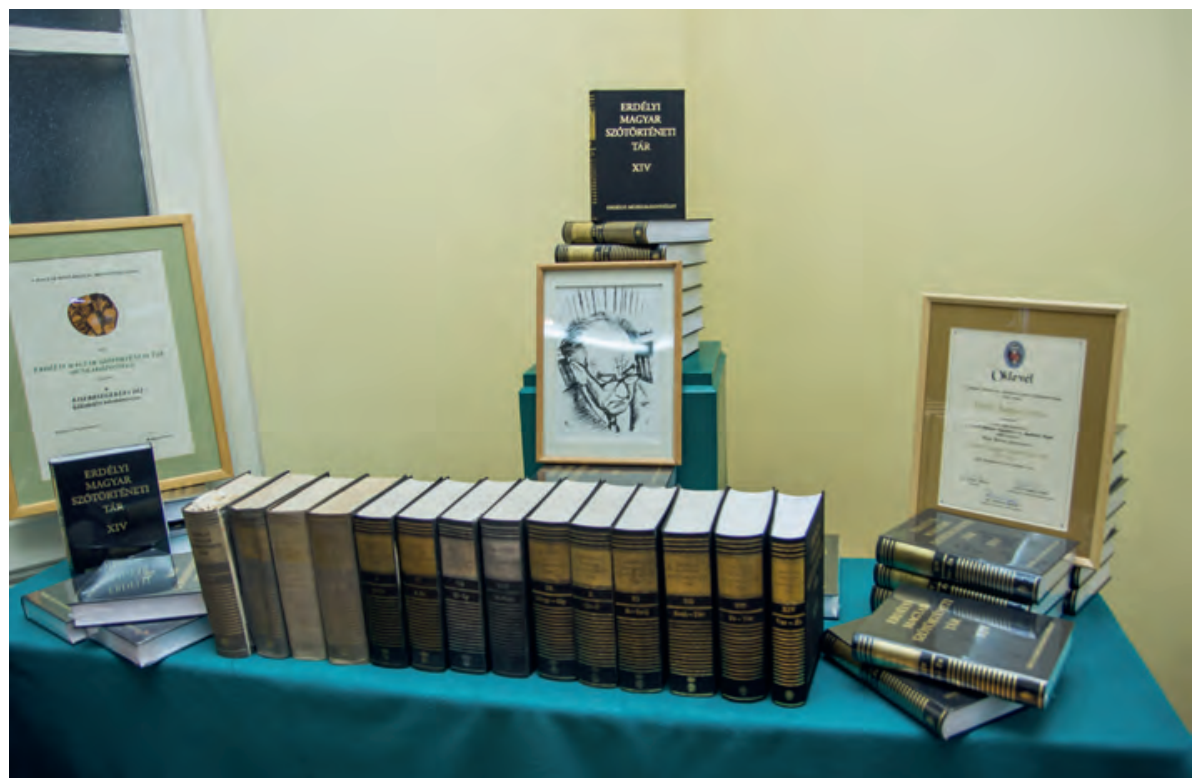

A befejezett Erdélyi magyar szótörténeti tár I4 kötete

\section{Az irodalomtörténészek kutatásai}

Biró Annamária és Papp Kinga kutatásai a I8-19. századi magyar irodalomra, a magyar-német irodalmi és kulturális kapcsolatok, valamint a régi magyar irodalom tanulmányozására terjednek ki. Biró Annamária sajtó alá rendezte Aranka György Erdély-történetét, illetve a magyar-német kapcsolatokra vonatkozó eredményeit Nemzetek Erdélyben. August Ludwig Schlözer és Aranka György vitája címú kötetében adta közre, valamint felvállalta Aranka György levelezésének összegyújtését és kiadását is. Papp Kinga az íráshasználat különböző formáit, az írásnak a mindennapi életben betöltött szerepét vizsgálja a nemesi családok vonatkozásában, de érdeklődési köre kiterjed a halotti és ünnepi orációk, az iskoladrámák, a történetírás más szövegtípusainak tanulmányozására is. Kötete 2015-ben jelent meg Tollforgató Kálnokiak címmel.

\section{A filozófus kutatásai}

Ilyés Szilárd kutatásai kolozsvári filozófiatörténészek könyvtári és kéziratos hagyatékának feltárására irányulnak. Ez idáig két hagyatékot sikerült feldolgozni. A kutatási eredmények ismertetését különféle konferenciák és publikációk tették lehetővé. 


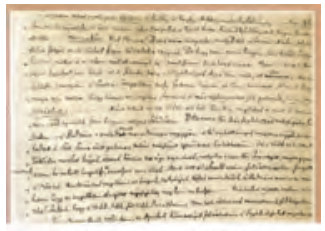

ARANKA GYOBGY GVOTIEMENYE

Aranka György

Erdély-története

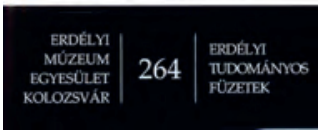

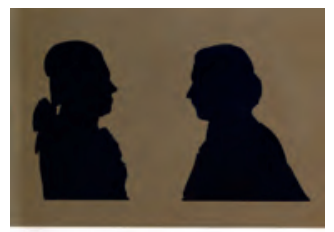

BIRO ANVAMÁRLA

Nemzetek Erdélyben August L.udwig Schlō̌er ès Aranka Gyōrgy vitaja

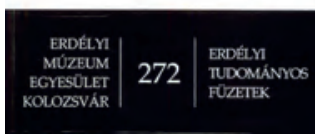

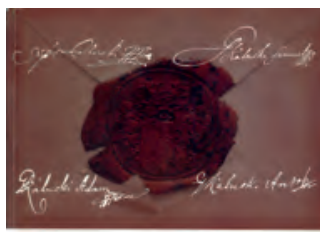

PAPP KINGA

Tollforgató Kälnokiak

Csalbdi irashhasnailat a 17-18. szizadi Erdélyben

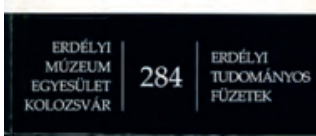

\section{A kutatóintézet külsó munkatársainak tevékenysége}

Az EME kutatási projektjei keretében időszakos kutatásokat is felkarol, közremúködve az egyes szakosztályokkal (pl. a 20I4-es évben összesen 30 személy végzett kutatást Io projekt keretében). A kutatásban részt vevő fiatal kutatók munkáját egyetemi oktatók irányítják, ezzel segítve, ösztönözve az egyetemen folyó kutatási tevékenységeket, szakkörök múködését.

A kutatóintézet külsó munkatársainak jelentósebb kutatásai, eredményei MAgYAR ÉS ÖSSZEHASONLÍTÓ IRODALOM- ÉS SZÍNHÁZTUdOMÁNYI KUTATÁsok. Kutatásvezető: Egyed Emese egyetemi tanár.

2006-20ı6 között az EME Magyar- és összehasonlító irodalomtudományi, illetve színháztudományi múhelye Egyed Emese vezetésével havonta tartotta múhelyfoglalkozásait.

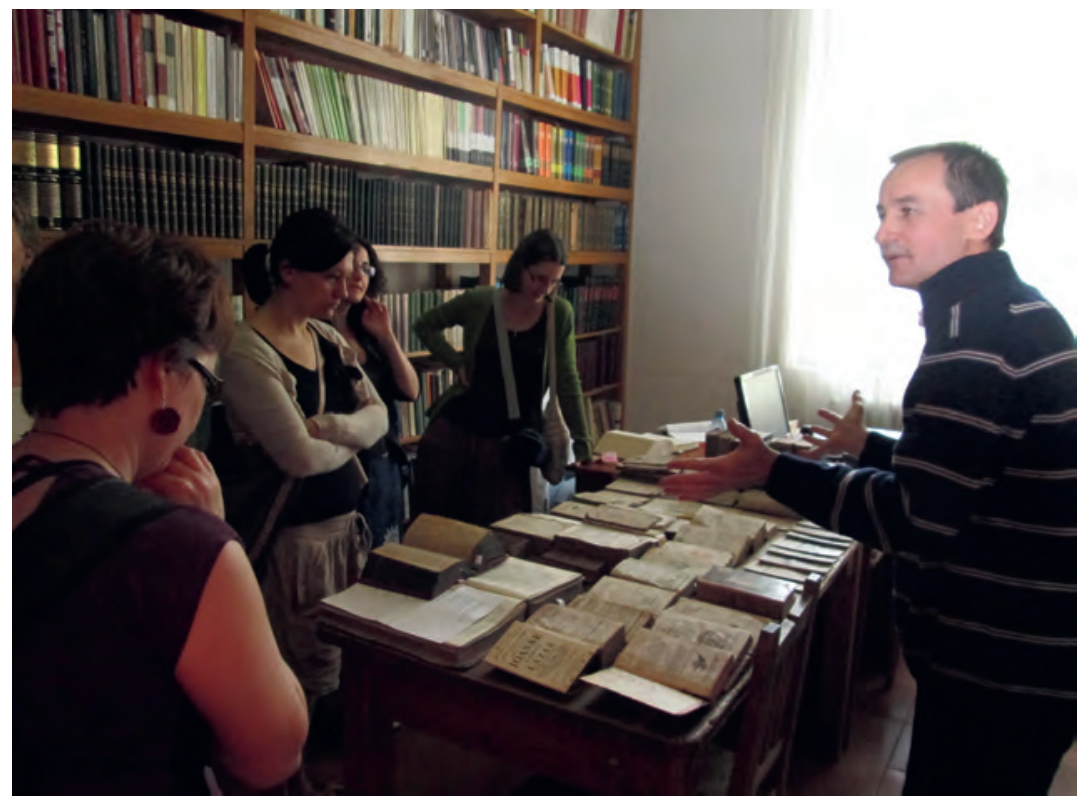



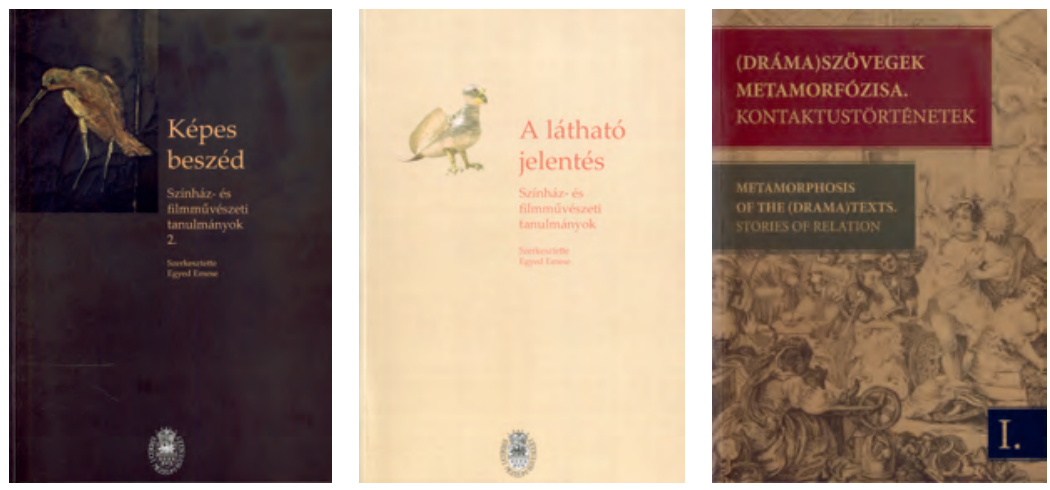

A kutatócsoport a forrásfeltárás mellett nagy hangsúlyt fektet a romániai és külföldi egyetemekkel és kutatóintézetekkel való együttmúködésre és a jövő kutatónemzedékének kinevelésére, a szakmai kapcsolatok létrehozására és fenntartására. Ennek jegyében a fiatal munkatársak külföldön is folytattak kutatásokat (Finnország, Franciaország, Németország, Ausztria), illetve részt vettek mind hazai (MTNE), mind külföldi, idegen nyelvú kongresszusokon és rangos szakmai tanácskozásokon. Eredményeik az EME kiadójában szerzői kötet, tanulmánykötet, illetve kommentált szövegkiadás formájában meg is jelentek.

A külső kutatók az elmúlt tíz évben a következók voltak: Bartha Katalin Ágnes, Boér Máté, Csata Adél, Demeter Zsuzsa, Kerti József, Rácz Emese, Varga P. Ildikó, Molnár Bodrogi Enikő, Sófalvi Emese, Tar Gabriella-Nóra. A csoport több tagja éppen ebben az évtizedben, a közös kutatások eredményeit és tapasztalatait is felhasználva, doktori fokozatot szerzett, illetve néhányan közülük szakmai kitüntetésben is részesültek: Varga P. Ildikó, illetőleg Demeter Zsuzsa az EME Debüt-díját nyerte el.

TechnikA- ÉS ipartörténeti kUtATÁsok ERdélyben. A kutatást 2006 óta szervezett keretek között folyamatosan múködtetjük egy interdiszciplináris program keretében: A múszaki örökség feltárása, kutatása és védelme Erdélyben ${ }^{13}$ címmel. A kutatási projekt révén technikai örökségünk felkutatása, múködőképessé tétele, megőrzése, kulturális örökségünkbe

13 Az EME Múszaki Tudományok Szakosztálya 2006 óta eredményesen múködteti A múszaki örökség feltárása, kutatása és védelme Erdélyben címú interdiszciplináris kutatási programját. A program az alábbi projekteket múködteti: Technikatörténeti kutatások; Archeometallurgiai kutatások; Múszakis nagyjaink kutatása, hagyatékainak feldolgozása; Ipartörténeti kutatások. (Lásd Bitay Enikő: A múszaki örökség feltárása, kutatása és védelme Erdélyben. In: Fedenic Csilla (szerk.): Magyar-magyar interdiszciplináris kutatások, intézményi együttmúködések lehetősége. Budapest, MTA - Magyar Tudományosság Külföldön Elnöki Bizottság, 2010. 70-76 p. 


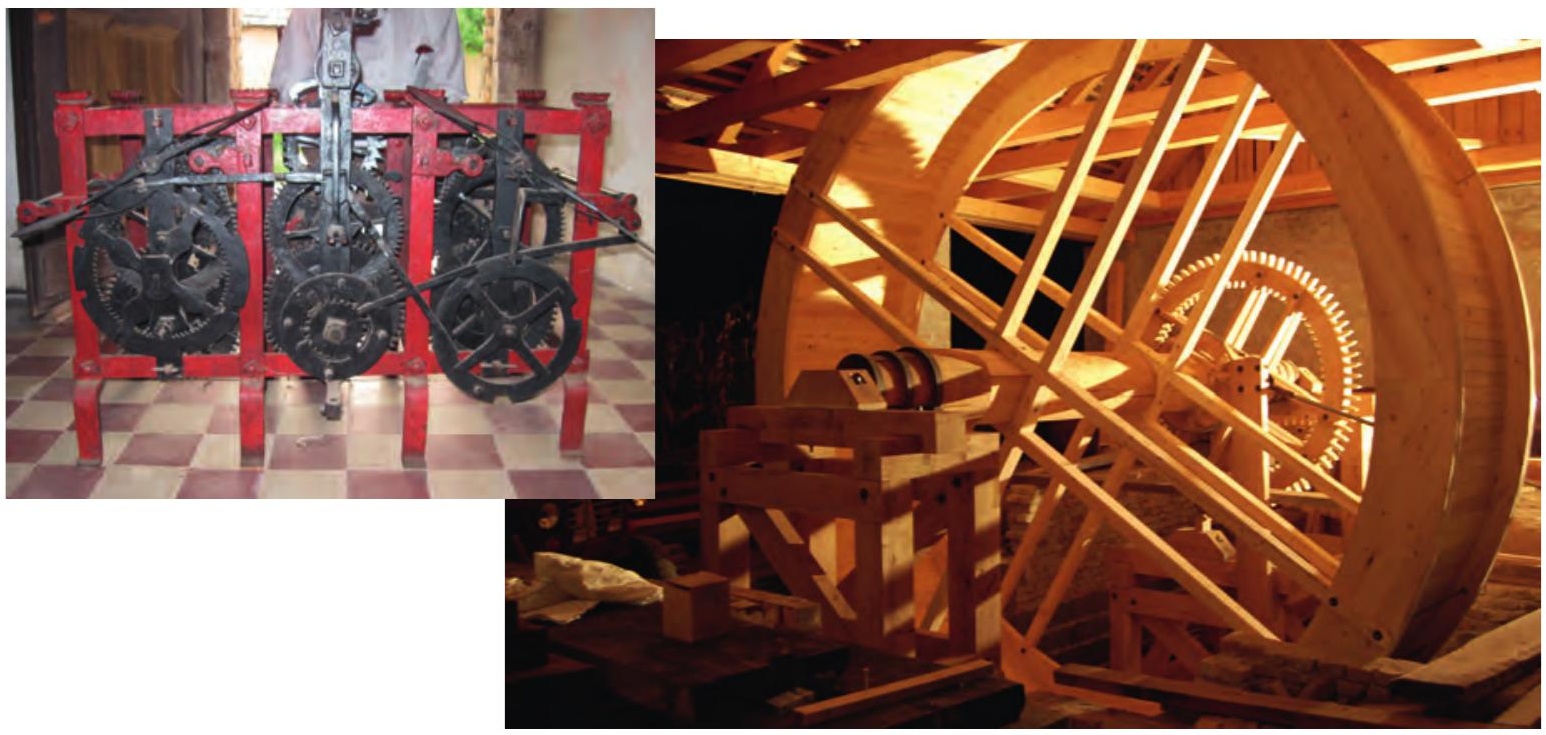

A gyerömonostori toronyóra (fent); a mohácsi taposómalom (jobbra)
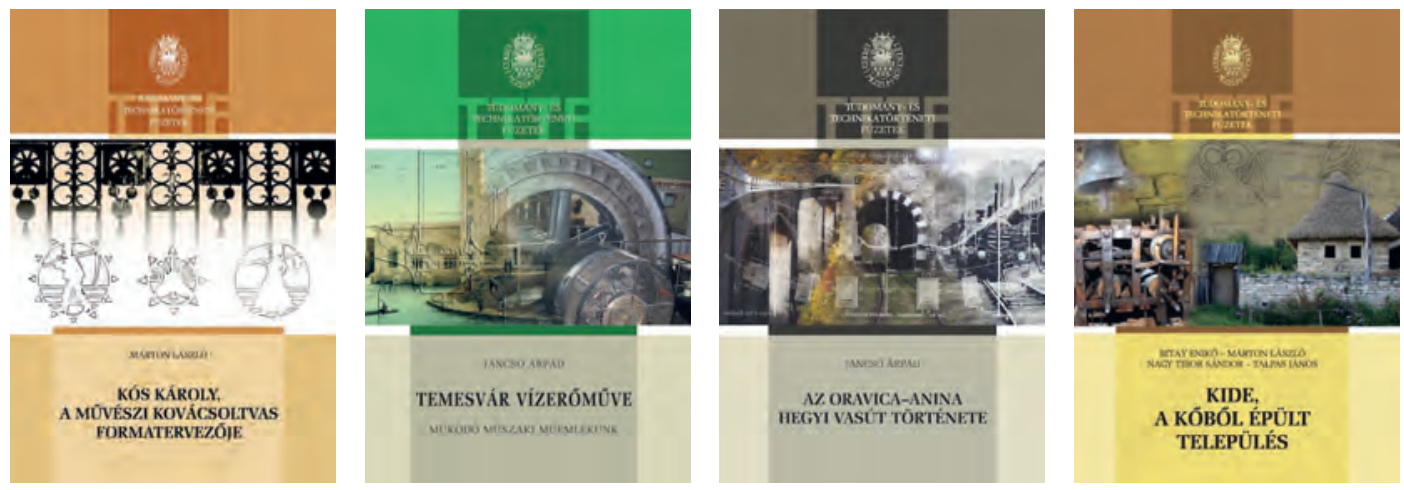

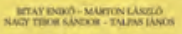

KIDE,

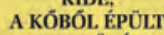
TELEPŪLÉS
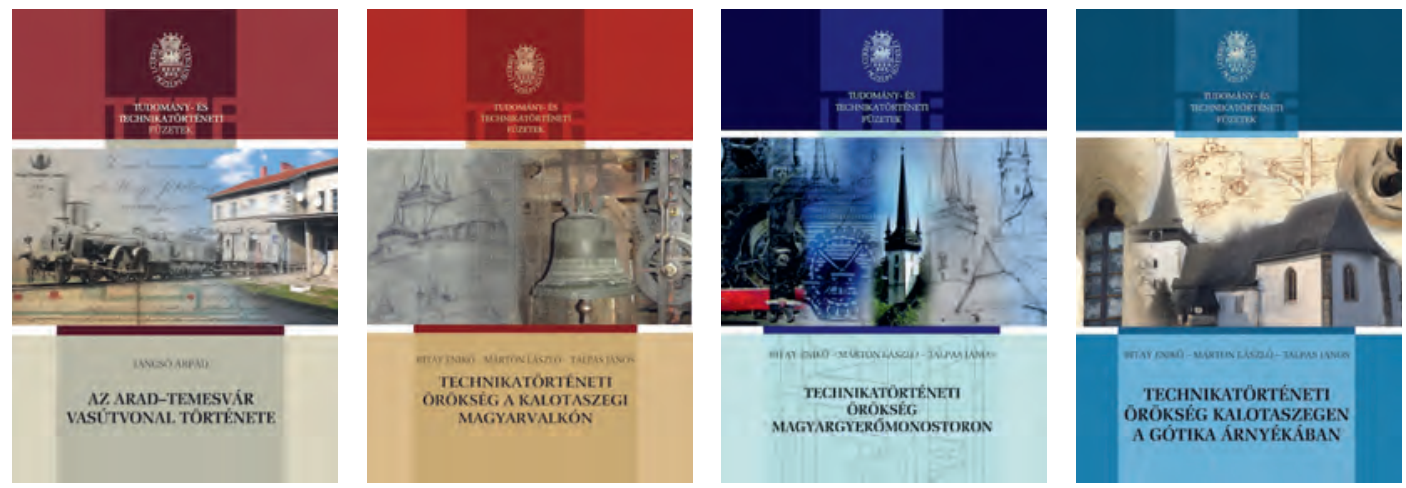

A tudomány-és technikatörténeti sorozat 
való integrálása, valamint a térség kulturális és turisztikai fejlesztése valósul meg. Évenként egy-két célirányú kutatási projekt valósult meg, az egyes kutatási projekteket Bitay Enikő egyetemi docens, Márton László kutatómérnök és Talpas János adjunktus vezették.

$\mathrm{Az}$ évenként megrendezett technikatörténeti alkotótáborok képez (ték)ik azoknak a felméréseknek az alapját, melyek révén az egyes térségek technikatörténeti örökségéről szóló kötetek létrejöttek. Az első kötet 2009-ben jelent meg. A kötetek híven tükrözik a technikatörténeti kutatások, terepmunkák, levéltári forrásgyújtések és felmérések eredményeit. Eddig 8 kötet jelent meg, s további négyen dolgoznak a kutatócsoport tagjai. A kötetek online elérhetók az EDA-ban: https://eda.eme.ro/ handle/IO598/9740.

Egy másik jelentős eredménye a kutatásnak a technikatörténeti objektumok felújítása, avagy gyakorlati megvalósítása. Például a 20I5-ben avatott mohácsi taposómalom kivitelezése, muzeális szemléltetőeszközként, illetve a gyerőmonostori toronyóra felújítása, múködőképessé tétele (a toronyóra szintén muzeális objektumként lett kiállítva 20I6-ban a templomban).

IPARRÉGÉSZETI, ARCHEOMETALLURGIAI ÉS ARCHEOMETRIAI KUTATÁSoK. Kutatásvezető: Veres Erzsébet ny. egyetemi docens. Az interdiszciplináris kutatást a régészeti ásatások során előkerült egyes vas- és cserépleletek készítéséhez használt nyersanyagok származási helyének anyagtudományi módszerekkel való (archeometriai) vizsgálata képezte.

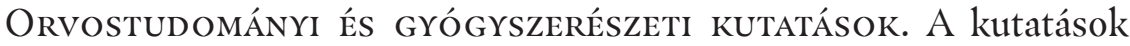
témakörei 20II-ben preklinikai (idegélettani) és klinikai (daganatpatológiai) kutatásokra, valamint gyógyszerészeti (gyógyszerforma-tervezés), míg 20I4-ben genetikai, gyógyszerészeti és fogorvosi kutatásokra terjedtek ki.

A kutatásvezetők irányításával lehetőség nyílt magyar PhD-hallgatóknak, egyetemi oktatóknak ezekbe a kutatásokba bekapcsolódni, valamint a kapott eredményeket rangos szakmai lapokban publikálni.

Óslénytani kUtATÁsok. Egyéni kUtató: VRemir Mátyás. Kutatásai a gerinces paleontológia terén három fó irányban zajlottak:

- felső-kréta kori ősemlősök (Mammalia, Multituberculata) diverzitása és földrajzi-rétegtani elterjedése;

- a szászsebesi és hátszegi régióbeli felső-kréta kori repülő sárkány (Pterosauria) taxonómiai diverzitása és rétegtani elterjedése;

- a Szászsebes környéki felső-maastrichti törpe dinoszauruszok fészkelőhelyei és fészkelőstratégiái.

Vremir Mátyás kutatásai főként nemzetközi együttmúködések kereté- 

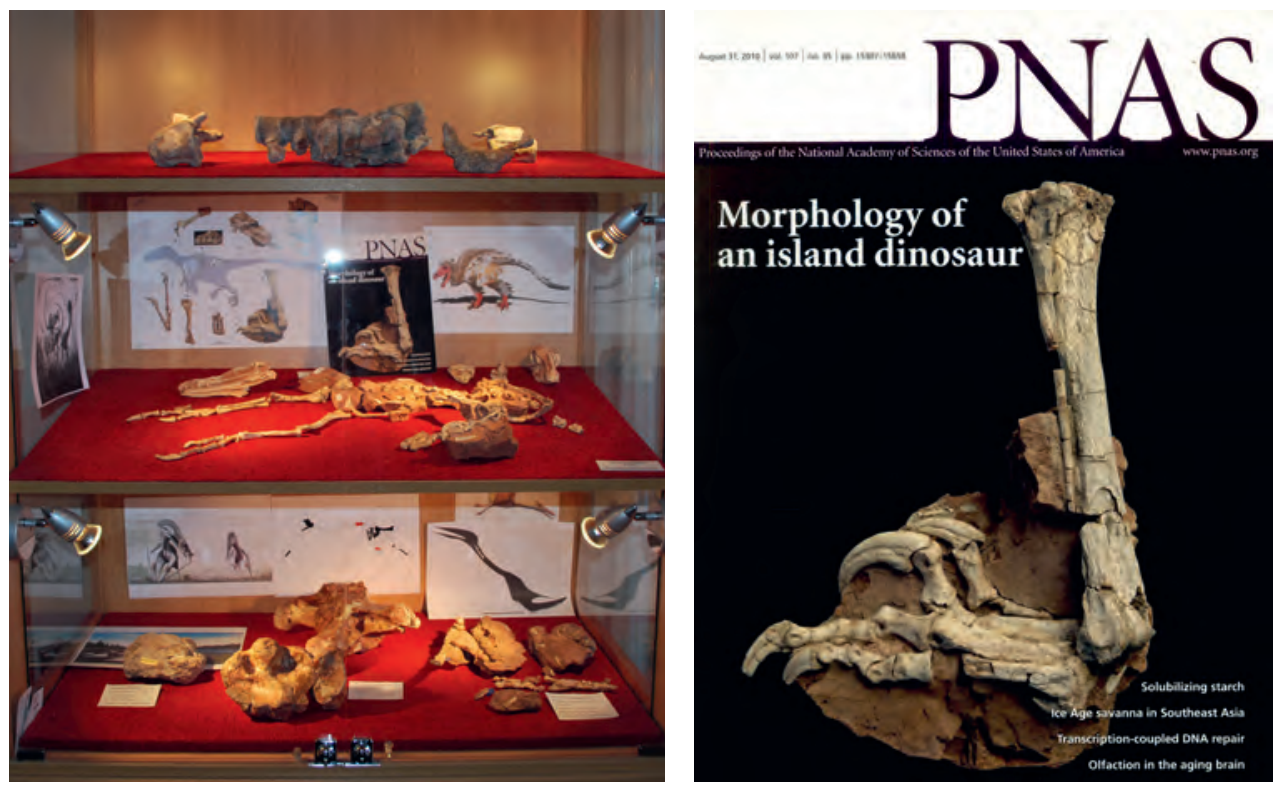

ben foly(tak)nak, az eredményeket számos rangos, nemzetközileg jegyzett publikációban közölte.

A kutatóintézet külsó munkatársainak egyéb kutatásai, eredményei.

A felsorolt kutatások kiegészítéseként szükséges megemlítenem, hogy a helyszúke miatt csak néhány kutatási programot s ezek eredményeit tekinthettük át, melyek többnyire folyamatosan múködtek, hosszabb távon. Ezenkívül más tudományterületeken is folytak időszakos kutatások, mint például a növénytan, matematika-informatika, agronómia, társadalomtudomány, közgazdaságtan területén, melyek megvalósításában az egyes szakosztályok jelentős szerepet vállaltak. Hogy csak néhány példát említsünk:

- Egyesületünk biológiai kutatócsoportja (Szabó Anna, Ruprecht Eszter) több éven keresztül magyarországi kutatókkal közös programban tárta fel az erdélyi Mezőség növényvilágát.

- Vincze Mária emeritus professzor irányításával zajlott A vidékfejlesztés területi különbözóségei az adottságok és a támogatások nézőpontjából a 2007-20II-es időszakban. Felkészülés a jövóbeli új kihívásokra elnevezésú agrárpolitikai projekt, amelynek hosszú távú céljai között szerepelt az is, hogy a romániai döntéshozók a kutatási eredményeket figyelembe véve szakszerúbben dolgozhassák ki a 20I4-2020-ra vonatkozó vidékfejlesztési projektet. Az eredmények könyvfejezetekben öltöttek testet. 
- Guttmann Márta vegyészkutató interdiszciplináris jellegú projektet irányított erdélyi múemlékek, mútárgyak festett felületeinek tudományos vizsgálata érdekében.

- Nyárádi Imre-István egyetemi adjunktus irányításával zajlott $A$ tápanyagellátás hatása a máriatövis (Silybum marianum) növekedésdinamikájára, terméshozamára, valamint a gyógyhatásért felelós hatóanyag mennyiségére címú program, melynek célja volt, hogy megteremtse azt a szakmai hátteret, amely új lehetóségeket nyit, és biztosítja a gyógynövénytermesztők technológiailag hatékony és gazdaságos termesztési tevékenységét, illetve biztosítja a fenntarthatóságot.

- A Darvai Zsolt egyetemi adjunktus vezette Folytonos optimalizálás és alkalmazási hatások elnevezésú pályázatot évek óta támogatja az EME. A pályázatból kiderül, a gazdasági, mérnöki vagy más jellegú gyakorlati feladatoknak széles köre vezethetó vissza az operációkutatás területén vizsgált optimalizálási problémákra.

- Tőkés Gyöngyvér adjunktus Virtuális közösségek, virtuális habitusok. Erdélyi képek a digitális világból elnevezésú projektjének célja az erdélyi magyar fiatalok virtuális jelenlétének és digitális szokásainak vizsgálata volt.

- Sipos Gábor egyetemi docens Erdélyi és partiumi magyar könyvtárak védett állományának kutatása és feldolgozása címmel vezetett kutatást. A projekt célja az I85I előtti nyomtatványok és kéziratok összegyújtése, kutatása és feldolgozása, valamint központi helyeken való biztonságos elhelyezése (pl. esperességi, egyházmegyei központokban vagy rendházakban), az állomány provenienciakutatása és ezzel az egyes gyúijtemények történetének feltárása.

- Dr. Theisz Rezső kutatásai a gyümölcsfák (alma, dió) kórokozókkal szembeni ellenállásának vizsgálatára irányultak.

A felsorolás folytatható lenne, ám úgy érzem, ennyi is elég ahhoz, hogy érzékelhessük, az EME külső kutatócsoportjai folyamatosan és következetesen végzik tevékenységülket, kutatásaik egymásra épülnek, esetleg éppen interdiszciplináris jellegükből fakadóan más tudományterületek kutatóinak továbblépését, széles látókörét biztosítják, a tudományterületek közti közremúk ködést serkentik. Tíz év alatt összesen 122 projektet múködtettünk külső munkatársak révén, 354 ösztöndíjas megbízott kutatóval, majd minden szakterületet felölelve. 


\section{Az EME fontosabb kutatási eredményei az elmúlt idöszakban}

Az utóbbi évek három legfontosabb eredményét emeljük ki, nevezetesen:

- Az Intézmények és politikai vezetôréteg a Szilágyságban a XIV-XVII. században címú projekt sikeres megvalósítását, melyet a Felsőoktatási és Egyetemi Kutatási Alap (CNCSIS-UEFISCSU, PN II-RU cod/20IO, TE_204) finanszírozott. Ez a kutatási projekt az EME egyik sikertörténete, hiszen román állami pénzből magyar intézmény 4 munkatársa, magyar témában kutathatott 3 éven keresztül teljes finanszírozással.

- 20I4-ben jelent meg az Erdélyi magyar szótörténeti tár XIV. kötete, s ezzel lezárult a Szabó T. Attila által elkezdett monumentális alkotás szerkesztése.

- Intézményünk paleontológiai gyưjiteménye őslénytani leletekkel bóvült (melyeket kiállítottunk), s jelentős kutatási eredményekkel járult hozzá a nemzetközi tudományossághoz.

Az EME keretében folyó sokágú tudományos kutatómunka méltatásakor ki kell emelnem, hogy a nemzeti/honismereti kutatásokra szakosodott Kutatóintézet fóállású tudományos munkatársai nemzetközi szinten is jegyzett fontos eredményeket értek el a történelmi források kiadása, az irodalomtörténeti vagy nyelvészeti témák feltárása révén, a Kutatóintézet fenntartása tehát elsőrendű feladata Egyesületünknek.
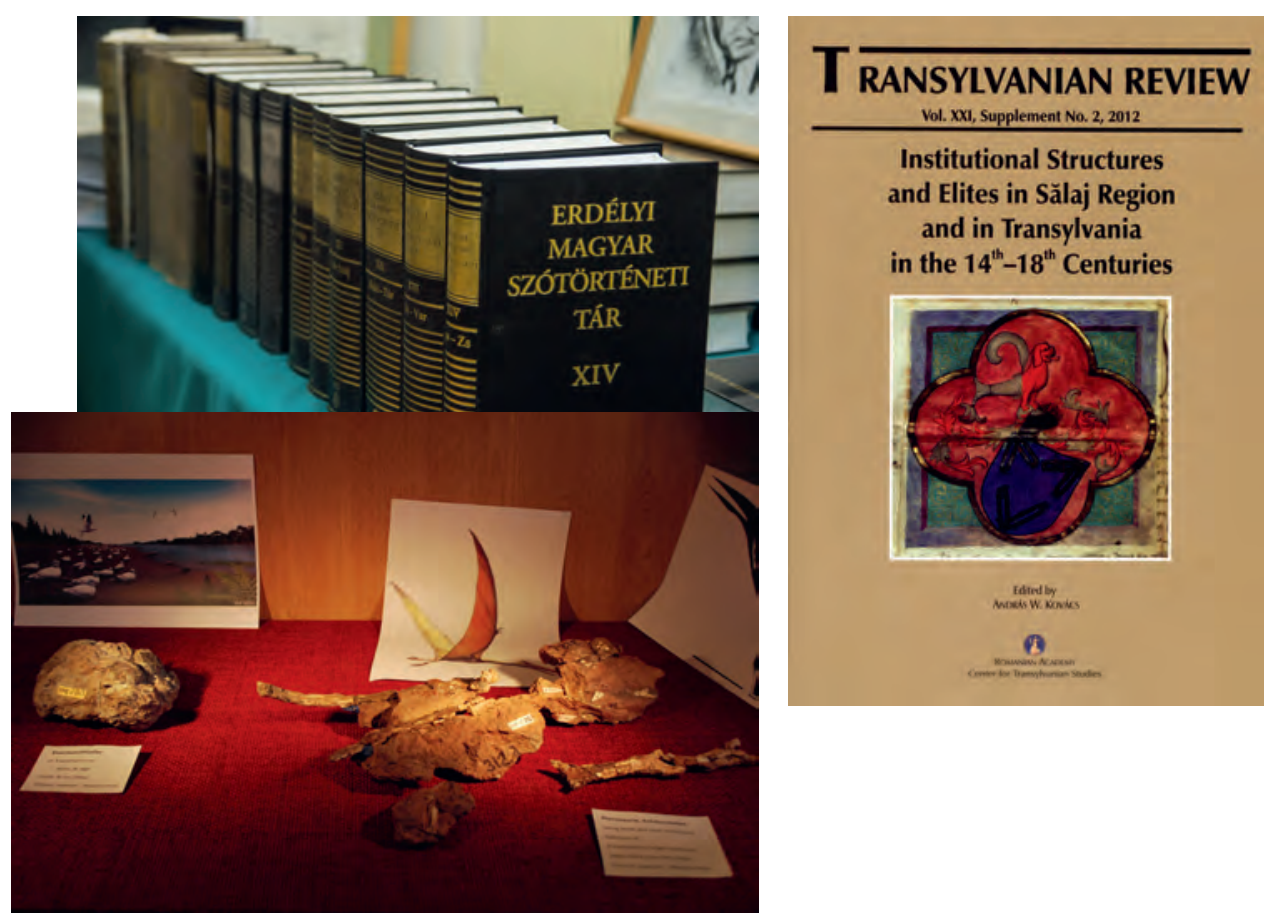


\section{SZAKMAI KÉPZÉSEK, TUDOMÁNYOS \\ RENDEZVÉNYEK}

Az EME múködése során sokszor felvállalt a tudományosság jegyében olyan feladatokat, amelyekre az adott időszakban közösségünknek nagy szüksége volt. Két példát emelnék ki:

- Az EME MTSZ-a 1996-ban indította el a Fiatal Múszakiak Tudományos Ülésszakát, azt a fórumot, amely a magyar nyelvú múszaki képzés hiányában jelentős kezdeményezésnek számított. Hozzájárult a magyar múszaki nyelv múveléséhez s a fiatal múszakis oktatók utánpótlásához.

- Az Orvos- és Gyógyszerésztudományi Szakosztály kreditpontos szakmai képzése, mely az orvostársadalom szakmai előmeneteléhez járult s járul jelenleg is hozzá.

Ugyancsak nagy jelentőségú és eredményes volt Gálfi Emőke kutatónk, kolléganőnk éveken keresztül tartott latinképzése. A régészhallgatók mellett a történelem szakos diákok is bekapcsolódtak a képzésbe, és igény volt a kora újkori források bevonására is. Hasonlóan hasznosnak, eredményesnek értékelhető Talpas János egyetemi adjunktus tagtársunk több éven keresztül szervezett rendezvényei, melyek a szakmai képzés jegyében is zajlottak: a Technikatörténeti alkotótábor, az Erdélyi barangolás címú szakmai programok.

Az EME által folytatott tudományterjesztésnek és tudomány-népszerúsítésnek legfőbb mozgatói, a szakosztályok számos konferencia, tudományos ülésszak, felolvasoülés, emléknap, szakmai fórum szervezői, társszervezői voltak. Csupán a 2015-ös évben összesen IOZ rendezvénynek (melyből 26 konferencia, 2I könyvbemutató, négy kiállítás és egyéb rendezvények) volt házigazdája az EME.
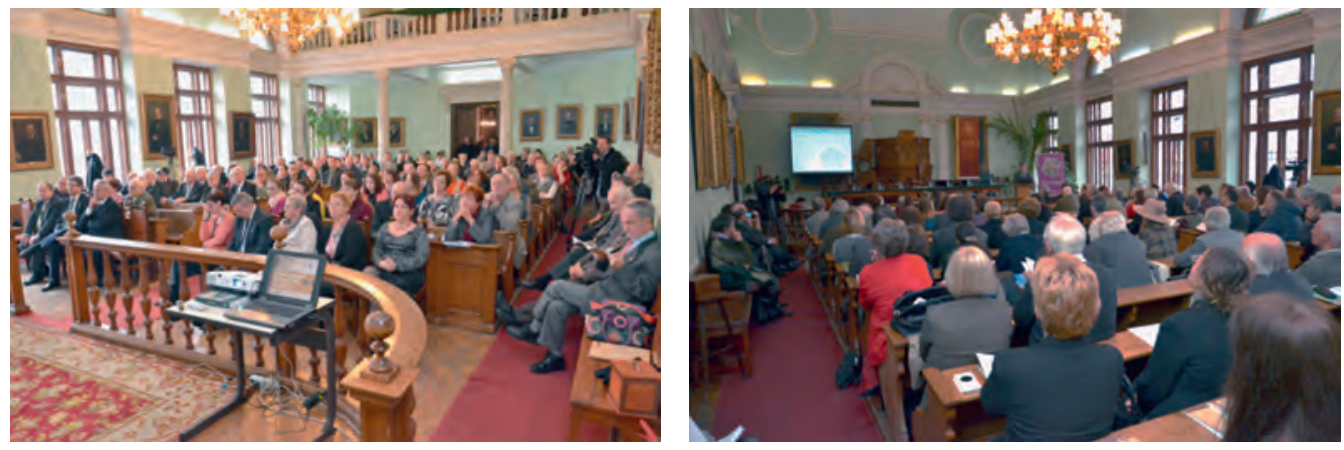

Az EME rendezvényei: a Magyar Tudomány Napja központi rendezvénye, 2015. november 20. 


\section{AZ ERDÉLYI DIGITÁlIS ADATTÁR (EDA) \\ MỨKÖDTETÉSE ÉS FEJLESZTÉSE}

Az EME 2OII-ben kiépítette szabad hozzáférésú intézményi repozitóriumát, az Erdélyi digitális adattárat. A digitalizálási programok által igyekszünk online hozzáférhetővé tenni mind az erdélyi tudományos örökséget, mind a legfrissebb szakirodalmat és kutatási eredményeket. A kilenc egységből (tárból) álló digitális adattár, elsősorban az EME régi kiadványainak digitális változatát, gyúiteményeinek adatait, illetve az erdélyi magyarság múltjával kapcsolatos történeti forrásokat tartalmazza, folyamatosan bővül.

2015 végéig 2I ooo tételre gyarapodott az adattár, melynek elérhetősége: $h t t p s: / / e d a . e m e . r o /$.

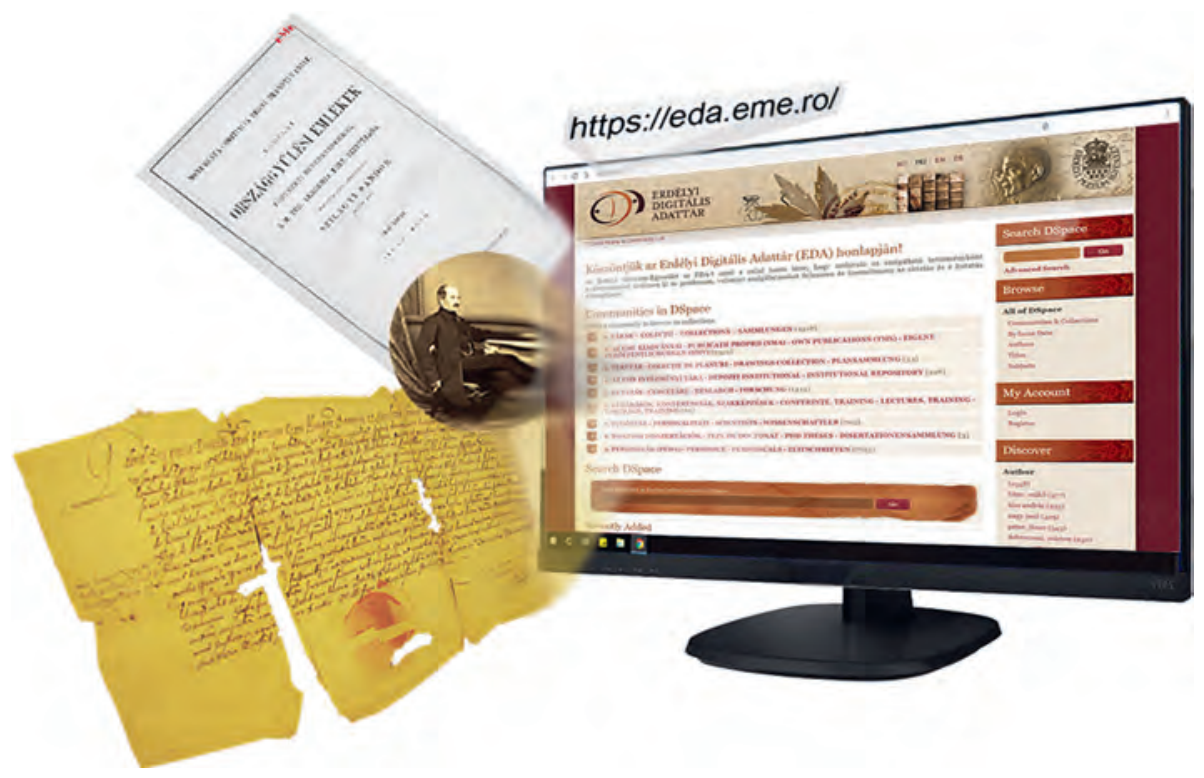

Az EME intézményi repozitóriuma, az Erdélyi digitális adattár (EDA)

Az EDA elismert tudományos adattár, hiszen tételeit (adatait, metaadatait) a Google tudóstár, a Worldcat automatikusan, folyamatosan átemeli jegyzékébe, ugyanakkor az MTA Magyar Tudományos Múvek Tára külső azonosítóinak lajstromában is szerepel.

\section{TUDOMÁNYOS KÖNYV- ÉS FOLYÓIRAT-KIADÁS}

Az EME kiadványai a tudományos eredmények közlésén túl a magyar tudományos nyelv fenntartásának és fejlesztésének nem csökkenő fontosságú nemzeti feladatát szolgálják, ez az erdélyi magyarság jövője szempontjából is létfontosságú. 
Az Erdélyi Múzeum-Egyesület már az I860-as években is saját kiadásában jelentette meg a gyújteményei feldolgozása nyomán keletkezett tudományos munkákat, és több tudományos folyóiratot is kiadott. A kiadványok a bölcsészet-, orvos- és természettudományok területeinek legújabb kutatási eredményeit mutatták be.

Az EME 199I-ben újraindította az Erdélyi Múzeum címú folyóiratot, amelynek azóta is évi 4 száma jelenik meg. Az Orvostudományi Értesító és az Acta Scientiarium Translvanica címú folyóiratok kiadása szintén folyamatos. Korábbi könyvsorozata folytatásaképpen jelent meg I99I-ben az Erdélyi Tudományos Füzetek 209. száma, amely ma is folyamatosan bövül. Ebben a sorozatban jelennek meg az egyesület kutatóintézete munkatársainak múvei, doktori értekezések, forráskiadványok és elméleti munkák, konferenciakötetek, túlnyomó részük a bölcsészettudományok területéről származik.

A Székely oklevéltár új sorozatának négy vaskos (IV-VII.) kötete az EME egyik fontos kiadványa a történelmi források kiadása körében. Az Erdélyi Történelmi Adatok, valamint az Erdélyi Nemzeti Múzeum Levéltára sorozatai az EME kutatóintézetében folyó forrásfeltáró munkáknak ad megjelenési lehetóséget.

Ugyancsak az EME vállalta fel Szabó T. Attila monumentális munkájának, az Erdélyi magyar szótörténeti tárnak a folytatólagos kiadását, ezt a I4. kötettel sikerült is befejezni.

Jelentős újítása volt a kiadónak a kilencvenes évek után, hogy új sorozatokban teret biztosított a múszaki kutatások eredményeinek megjelentetésére. Míg a Múszaki Tudományos Füzetek sorozata a legújabb tudományos eredmények publikálásával a magyar múszaki szaknyelv fejlesztésére is vállalkozik, a Tudomány-és Technikatörténeti Füzetek sorozata az erdélyi technikai örökség feltárásával indult, a továbbiakban emellett tudománytörténeti munkákat fog megjelentetni, a Müszaki Tudományos Közlemények sorozat pedig a tudományos ülésszakokon elhangzott előadások írott változatait fúzi egy csokorba évente megjelenő két számában.

A tudományos kutatásokat segíto jelentős segédkiadványok, lexikonok (mindenekelött a Romániai magyar irodalmi lexikon 4., illetve 5/I. és 5/2. kötete a Kriterion Kiadóval közösen) és bibliográfiák kiadása is folyamatos, de ezek mellett jelentős az önálló kötetben megjelent múvek száma is, illetve a más kiadókkal közösen felvállalt kiadványok (kötetek) megjelentetése is.

A kiadványok szakmai színvonalát esetről esetre felkért szaklektorok biztosítják. Az EME 2006 óta elismert akkreditált kiadónak számít a Nemzeti Felsőoktatási és Kutatási Tanács (CNCSIS) nyilvántartásában. 


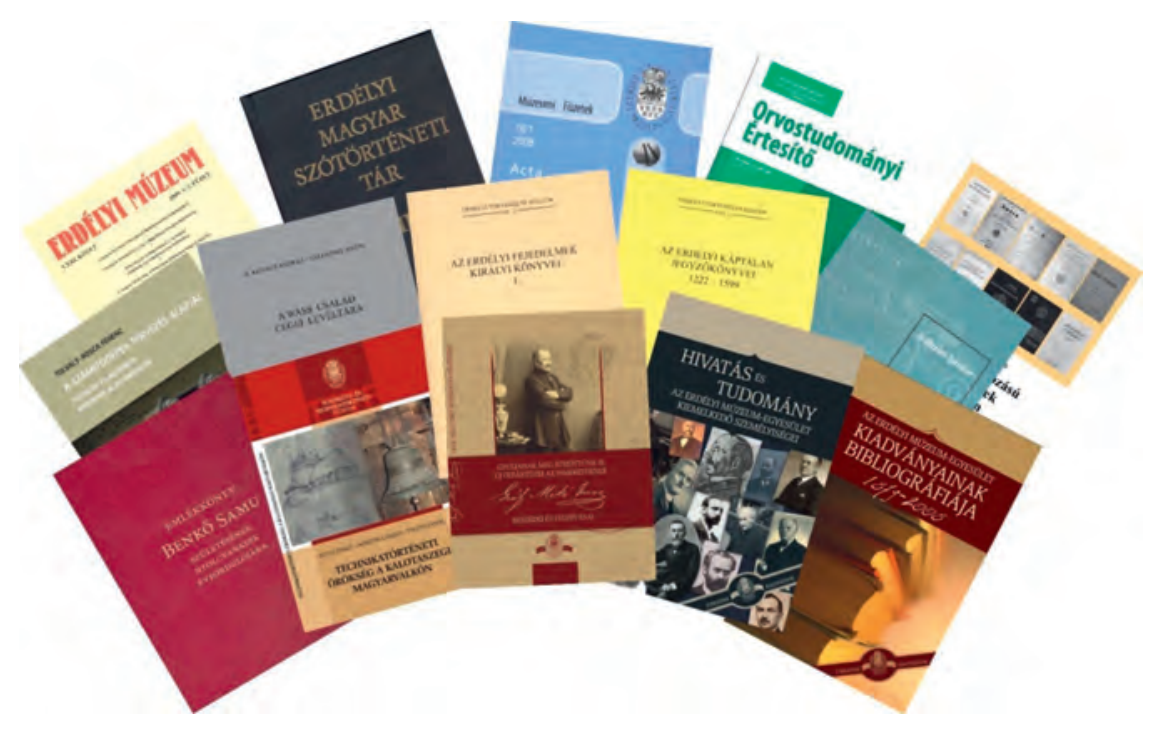

Az EME kiadványai

Jelenleg a kiadó $B$ kategóriás minősítéssel rendelkezik történelem, kultúratudományok és filológia kategóriában, valamint $C$ kategóriás az előadómúvészetek témakörben. Az Erdélyi Múzeum folyóirat szintén $B$ minösitésú a történelem és kultúratudományok, filozófia és filológia kategóriákban. ${ }^{14}$

Az Erdélyi Múzeum-Egyesület kiadója a rendszeresen kiadott szakfolyóiratok mellett évente több tudományos kötetet jelentet meg önállóan vagy más kiadókkal közösen. Például a 2015-ös év mérlege: 25 könyv és 8 folyóirat.

\section{EME-kiadványok 2005-2015}

Az elmúlt tíz év kiadványait tekintve elmondható, hogy folyóirataink közül az Erdélyi Múzeumnak összesen 30, a Múzeumi Füzetnek I7, a Dolgozatok az Erdélyi Múzeum Érem- és Régiségtárából-nak 5 és az Orvostudományi Értesítőnek 40 száma jelent meg. Sorozatköteteink lajstroma: Erdélyi Tudományos Füzetek - 33; Erdélyi Történelmi Adatok - 4; Múszaki Tudományos Füzetek - FMTÜ - IO; Erdélyi magyar szótörténeti tár - 3; Romániai magyar irodalmi lexikon - 2; Múszaki Tudományos Füzetek - 8; Erdélyi Nemzeti

14 Megjegyzés: A Tudományos Kutatás Nemzeti Tanácsa (CNCS) által B minősítésúként elfogadott kiadványok az egyetemi tanárok, doktoranduszok és a romániai tudományos életben részt vevő kutatók számára létfontosságúak, ugyanis csak ezek alapján lehet az egyetemi életben előléptetéseket elérni és pályázatokat nyerni. 
Múzeum Levéltára - I; Tudomány-és Technikatörténeti Füzetek - 8; Emberek és Kontextusok - 8; Kölesériana - I; Certamen - 2; Letöltés. Média- és kommunikációtudományi könyvsorozat - 2; Múszaki Tudományos Közlemények - 3; Romániai magyar bibliográfiák I954-I959 - I. Önálló kötetek: összesen 7I, más kiadóval közösen kiadott kötetek I6, illetve 2 CD látott napvilágot.

Összegezve az elmúlt Io év mérlege: I 75 könyv és 92 folyóiratszám.

\section{A jövendó céljai}

Egy nagyobb időszak eredményeinek áttekintése végén a jövőbeli tervekre is szükséges kitérnünk. Mint láthattuk, az EME stabil intézményes keretet alakított ki a tudományosság szolgálatában. Mindezek megtartása, folyamatos múködtetése lehet a jövőbeli célunk.

Nem kevésbé céljaink közé sorolhatjuk a térség tudományos életének fellendítését, kutatási programok múködtetését több szakterületen, ezenbelïl olyan (magyar nyelvú) interdiszciplináris kutatások támogatását, amelyek más intézményekben nem kapnak teret. Az ifjú szakemberek támogatása, szakképzése, a tudós generáció nevelése által az EME az egyetemek háttérintézményeként is szolgál. A tudományos hagyatékok elkallódástól

$\frac{\text { Könyvtár }}{\text { 乡 }}$

Kézirattár

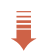

INFORMÁCIÓS ÉS DOKUMENTÁCIÓS KÖZPONT

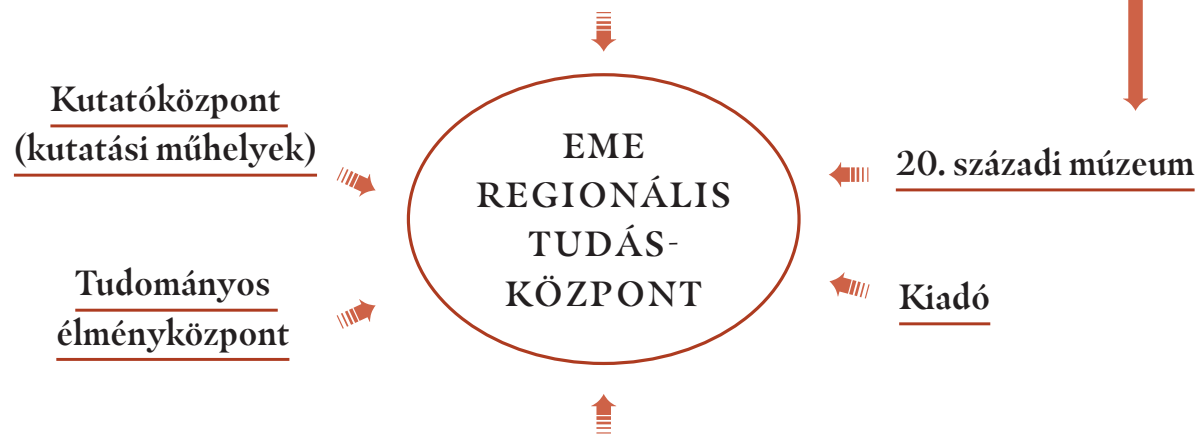

Szakosztályok/fiókegyesületek/szakcsoportok

Az EME - Regionális tudásközpont szerkezete 
való megmentése, szakszerú tárolása, feldolgozása; digitális közzététele, kutatási dokumentációs forrásanyagként való hasznosítása elengedhetetlen. A magyar nyelvứ tudománymúvelés ösztönzése, a tudományos eredmények közzététele (kiadója révén), terjesztése a világhálón (EDA), illetve tudomány-népszerúsíto előadásokon (szakosztályok szervezésében) ugyancsak fontos szempont.

Az EME mint regionális tudásközpont otthont biztosíthat az egyesület tevékenységeinek, intézményeinek a múködésére, illetve kulturális és közösségi funkciói által meghatározó, központi intézménnyé válhat a kolozsvári, erdélyi és a Kárpát-medence magyarsága számára.

A történelem igazolta, hogy az EME tudományos életének jelenléte a romániai magyar társadalomban mindig meghatározó szerepú volt: a kezdeti múzeumi értékek gyújtésével, majd az I872-es egyetemalapításban játszott szerepével, a rendszerváltásokat követően pedig intézményként a tudós társadalom összefogó kötelékeként, folyamatosan megjelenő kiadványaival, a tudomány terjesztésében, népszerúsítésében vállalat szerepével stb. Az EME a jövőben is be kívánja tölteni ezt a sokrétú szerepet, hogy kiemelten erősítse azt a tartópillérét, amelyre közösségünknek a legnagyobb szüksége lesz; azt fogja eredményesen múködtetni, fenntartani. Mindezt a sajátos, egyedi szervezeti felépítést kívánja szolgálni a Regionális tudásközpont tervezete is, mely az EME egységeit (pilléreit) intézményes keretben s egymást erősítő összhangban kívánja múködtetni, a tudományosság jegyében.

\section{Zárszó}

Az együttmúködések jelentőségét emelném ki zárszóként. Azon együttmúködéseket, melyek fontos elemei a tudományos életnek: a kutatásszervezés, a kutatási témák, a digitalizálási programok összehangolása, egymás értékteremtő tevékenységének megismerése, elismerése. Ez a fórum is erre hivatott, ezt szolgálta és szolgálja azáltal, hogy I8 intézmény tudományos törekvéseibe tekinthettünk bele.

Csakis egymás tudományos tevékenységének megismerése, értékelése, tisztelete és az összehangolt együttmúködés adhat alapot a kisebbségben múk ödő hatékony tudományfejlődésnek. 


\section{IRODALOM}

- Bíró Vencel: A kolozsvári jezsuita egyetem szervezete és építkezése a XVIII. században. Kolozsvár, 1945 (Erdélyi Tudományos Füzetek 192.), http:// eda.eme.ro/handle/I0598/87IO

- Bitay Enikő: Fótitkári jelentés az Erdélyi Múzeum-Egyesület .... évi munkájáról. A 2007-2015. évi jelentések az Erdélyi Múzeum évfolyamaiban jelentek meg.

- Bitay Enikő: A múszaki örökség feltárása, kutatása és védelme Erdélyben. In: Fedenic Csilla (szerk.): Magyar-magyar interdiszciplináris kutatások, intézményi együttmúködések lehetősége. MTA, Magyar Tudományosság Külföldön Elnöki Bizottsága, Budapest, 20IO. 70-76., http://mta.hu/ data/dokumentumok/magyar_tudomanyossag_kulfoldon/MTA_konyv_ Magyar-magyar.pdf

- Bitay Enikő, Márton László, Mohácsi Bugárszki Norbert, Angi Norbert: Egy ókori gabonaőrló szerkezet - a taposómalom újjászületése. $=\mathrm{A} X \mathrm{XV}$. Múszaki Tudományos Ülésszak Előadásai. Proceedings of the $\mathrm{XV}^{\text {th }}$ International Conference of Technical Sciences, Múszaki Tudományos Közlemények 2. Szerk. Bitay Enikő, Máté Márton. Kolozsvár, EME, 2015. 55-60., https://eda.eme.ro/handle/10598/28548

- Bitay Enikő: A Keresztény Magvetó az Erdélyi digitális adattárban. The Christian Sower in the Transylvanian Digital Database. Keresztény Magvetö CXVIII(2012). I49-I69., https://eda.eme.ro/handle/I0598/27775

- Bitay Enikő: Az Erdélyi digitális adattár. Tudományos és múszaki tájékoztatás (MTM), LX(2013). 203-216., http://tmt.omikk.bme.hu/show_news. html?id=5784\&issue_id $=548$

- Erdélyi Pál: Az Erdélyi Múzeum félszázada. EM XXVII(I9IO). I-8., http:// eda.eme.ro/handle/I0598/4307

- Hofbauer László: Az erdélyi akadémiai mozgalmak története. A legrégibb idóktól az impériumváltozásig. = A történeti Erdély. Szerk. Asztalos Miklós. Erdélyi Férfiak Egyesülete, Bp., 1936. 70I-720., http://adatbank.transindex.ro/html/alcim_pdf932I.pdf

- Imre Sándor: Az E. M. E. és a nemzetnevelés. (Töredékes megjegyzések.).= Emlékkönyv az Erdélyi Múzeum-Egyesület félszázados ünnepére I859-1909. Szerk. Erdélyi Pál. EME, Kvár I909-1942. IO4-I08., http://eda.eme.ro/ handle/IO598/8846

- Jakab Elek: Aranka György és az erdélyi nyelvmúveló és kéziratkiadó társaság. Bp. I884.

- Jakó Zsigmond: Az erdélyi magyar tudományosság fordulóponton. Erdélyi Múzeum 65 (2003).3-4. sz. IO4. 
- Jancsó Elemér: Magyar tudományos élet Erdélyben 1918-tól napjainkig. Láthatár I937. I. sz. I3-20; 2. sz. 74-80., http://ispmn.gov.ro/uploads/oo6 Jancso_Magyar\%2otudomanyos\%2oelet.pdf

- Kelemen Lajos: Az Erdélyi Múzeum-Egyesület múltja és jelene. EME, Kolozsvár, I909. I-3.

- Kelemen Lajos: Törekvések egy erdélyi múzeum alapítására. EM XXVI (1909). 353-375., http://eda.eme.ro/handle/ro598/4297

- Kántor Lajos: Párhuzam az Erdélyi Múzeum-Egyesület és az Astra megalakulásában és korai múködésében. Erdélyi Tudományos Füzetek, ETF. II6. szám. EME, Kolozsvár, I940. http://eda.eme.ro/handle/ro598/8798

- Kántor Lajos: Hidvégi gróf Mikó Imre szózata I856-ban az Erdélyi Múzeum és az Erdélyi Múzeum-Egyesület megalakitása érdekében. Kolozsvár, I93I. (Erdélyi Tudományos Füzetek 37.)., http://eda.eme.ro/handle/IO598/8698

- Kántor Lajos: Czegei gróf Wass Ottilia, az Erdélyi Múzeum-Egyesület nagy jótevóje. Kolozsvár, 1938. (Erdélyi Tudományos Füzetek 96.)., http://eda. eme.ro/handle/I0598/8694

- Kántor Lajos: Az Erdélyi Múzeum Egyesület problémái. Kolozsvár, I930. (Erdélyi Tudományosfüzetek 23.).,https://eda.eme.ro/handle/I0598/8757

- Kelemen Lajos: Az Erdélyi Múzeum-Egyesület története. = Emlékkönyv az Erdélyi Múzeum-Egyesület félszázados ünnepére 1859-1909. Szerk. Erdélyi Pál. EME, Kvár 1909-1942. 5-79., http://eda.eme.ro/handle/I0598/8846

- Szabó T. Attila: Emlékkönyv az Erdélyi Múzeum-Egyesület félszázados ünnepére. EM XLVII(I942). 280-283., http://eda.eme.ro/handle/IO598/27027

- Kristóf György: Erdély tudományos élete az abszolutizmus korában az Erdélyi Múzeum Egyesület megalakulásáig (I859). EM XLIII(I938). 2IO-22I., http://eda.eme.ro/handle/ro598/28009

- Kozma Ferenc: Jakab Elek tudósitása az E. M. E. alakuló közgyúléséról. = Emlékkönyv az Erdélyi Múzeum-Egyesület félszázados ünnepére 1859-1909. Szerk. Erdélyi Pál. EME, Kolozsvár, I909-1942. 80-82., http://eda.eme. ro/handle/I0598/8846

- Gr. Kuun Géza: Erdélyi tudományos igyekezetek. EM XVII(I90o). I-I8. és 7I-8I., https://eda.eme.ro/handle/I0598/3550, https:/eda.eme.ro/handle/ I0598/3567

- Szabó Dénes: Az E. M. E. és a kolozsvári tudomány-egyetem. = Emlékkönyv az Erdélyi Múzeum-Egyesület félszázados ünnepére 1859-1909. Szerk. Erdélyi Pál. EME, Kolozsvár, I909-1942. 95-99., http://eda.eme.ro/ handle/IO598/8846 
- Szabó T. Attila: Az Erdélyi Múzeum-Egyesület története és feladatai. EME, Kolozsvár, I942. http://eda.eme.ro/xmlui/bitstream/handle/I0598/8847/ bi_I30507.pdf?sequence $=\mathrm{I}$

- Szabó T. Attila: A transylvan magyar társadalomkutatás. Hitel 1938. I. sz. I3-3I.

- Szilády Zoltán: Erdély és a magyar tudományosság. = A történeti Erdély. Szerk. Asztalos Miklós. Erdélyi Férfiak Egyesülete, Bp., 1936. 693-700. http://adatbank.transindex.ro/html/alcim_pdf9320.pdf

- Szilágyi Sándor: Az Erdélyi Országos Múzeum elözményei. Budapesti Szemle VII(I859). 325-348.

- Tavaszy Sándor: Magyar tudományos törekvések Erdélyben. EM, XXXV (1930). 215-230., http://www.epa.uz.ua/oo9oo/oo979/o0225/pdf/1930_ 35_07-9_215-230.pdf

- Tavaszy Sándor: A tudomány az élet szolgálatában. EM XXXVIII(I933). I-2., http://eda.eme.ro/handle/IO598/27759

- Tavaszy Sándor: A tudomány helye és szerepe a kultúra rendszerében. EM XLII (1937). 55-6I., http://eda.eme.ro/handle/I0598/27922

- Tavaszy Sándor: Tudományos feladataink, tekintettel az Erdélyi MúzeumEgyesület hetvenötéves múltjára. Az E. M. E. 1935. február I7-én tartott ünnepi közgyưllésén. EM XL(I935). I-I2., http://eda.eme.ro/handle/ I0598/27849 